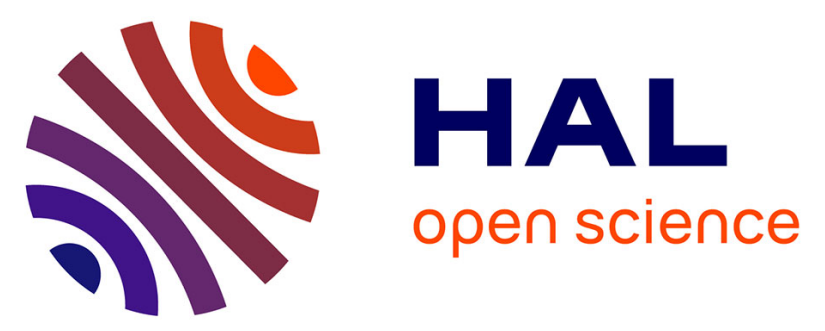

\title{
Inland human settlement in southern Arabia 55,000 years ago. New evidence from the Wadi Surdud Middle Paleolithic site complex, western Yemen
}

Anne Delagnes, Chantal Tribolo, Pascal Bertran, Michel Brenet, Rémy Crassard, Jacques Jaubert, Lamya Khalidi, Norbert Mercier, Sébastien Nomade, Stéphane Peigne, et al.

\section{To cite this version:}

Anne Delagnes, Chantal Tribolo, Pascal Bertran, Michel Brenet, Rémy Crassard, et al.. Inland human settlement in southern Arabia 55,000 years ago. New evidence from the Wadi Surdud Middle Paleolithic site complex, western Yemen. Journal of Human Evolution, 2012, 63 (3), pp.452 - 474. 10.1016/j.jhevol.2012.03.008 . hal-01828536

\section{HAL Id: hal-01828536 \\ https://hal.science/hal-01828536}

Submitted on 2 Sep 2018

HAL is a multi-disciplinary open access archive for the deposit and dissemination of scientific research documents, whether they are published or not. The documents may come from teaching and research institutions in France or abroad, or from public or private research centers.
L'archive ouverte pluridisciplinaire HAL, est destinée au dépôt et à la diffusion de documents scientifiques de niveau recherche, publiés ou non, émanant des établissements d'enseignement et de recherche français ou étrangers, des laboratoires publics ou privés. 


\title{
Inland human settlement in southern Arabia 55,000 years ago. New evidence from the Wadi Surdud Middle Paleolithic site complex, western Yemen
}

\author{
Anne Delagnes ${ }^{\mathrm{a}, *}$, Chantal Tribolo $^{\mathrm{b}}$, Pascal Bertran ${ }^{\mathrm{a}, \mathrm{c}}$, Michel Brenet $^{\mathrm{a}, \mathrm{c}}$, Rémy Crassard ${ }^{\mathrm{d}}$, \\ Jacques Jaubert ${ }^{\mathrm{a}}$, Lamya Khalidi $^{\mathrm{e}}$, Norbert Mercier ${ }^{\mathrm{b}}$, Sébastien Nomade $^{\mathrm{f}}$, Stéphane Peignég ${ }^{\mathrm{g}}$, Luca Sitzia ${ }^{\mathrm{a}}$, \\ Jean-François Tournepiche ${ }^{\mathrm{a}, \mathrm{h}}$, Mohammad Al-Halibi ${ }^{\mathrm{i}, \dagger},{ }^{\dagger}$ Ahmad Al-Mosabi ${ }^{\mathrm{i}}$, Roberto Macchiarelli ${ }^{\mathrm{j}, \mathrm{k}}$ \\ ${ }^{a}$ CNRS, Université Bordeaux 1, PACEA, Avenue des Facultés, 33405 Talence Cedex, France \\ ${ }^{\mathrm{b}}$ CNRS, Université Bordeaux 3, CRP2A-IRAMAT, Maison de l'Archéologie, 33607 Pessac, France \\ ' INRAP, 156 Avenue Jean Jaurès, 33600 Pessac, France \\ ${ }^{\mathrm{d}}$ CNRS, Université Lyon 2, Archéorient, Maison de l'Orient et de la Méditerranée, 7 rue Raulin, 69365 Lyon Cedex 7, France

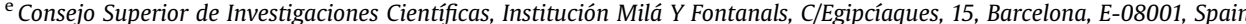 \\ ${ }^{\mathrm{f}}$ Laboratoire des Sciences du Climat et de l'Environnement, IPSL, CEA-CNRS-UVSQ Avenue de la Terrasse, 91198 Gif-sur-Yvette Cedex, France \\ ${ }^{g}$ Muséum National d'Histoire Naturelle, Département Histoire de la Terre, 8 rue Buffon, 75231 Paris Cedex 05, France \\ ${ }^{\mathrm{h}}$ Musée d'Angoulême, 1 rue Friedland, 16000 Angoulême, France \\ ${ }^{\mathrm{i}}$ General Organization for Antiquities and Museums, Ministry of Culture E' Tourism, Sana'a, Republic of Yemen \\ ${ }^{\mathrm{j}}$ Muséum National d'Histoire Naturelle, Département de Préhistoire, rue Buffon, bât. 140, 75005 Paris, France \\ ${ }^{\mathrm{k}}$ Université de Poitiers, Département Géosciences, rue A. Turpain, bât. B8 Sciences Naturelles, 86022 Poitiers, France
}

\section{A R T I C L E I N F O}

\section{Article history:}

Received 21 November 2011

Accepted 22 March 2012

Available online 4 July 2012

\section{Keywords:}

Arabian Peninsula

Yemen

Wadi Surdud site complex

Middle Paleolithic

OSL dating

Lithic technology

Settlement dynamics

\begin{abstract}
A B S T R A C T
The recovery at Shi'bat Dihya 1 (SD1) of a dense Middle Paleolithic human occupation dated to 55 ka BP sheds new light on the role of the Arabian Peninsula at the time of the alleged expansion of modern humans out of Africa. SD1 is part of a complex of Middle Paleolithic sites cut by the Wadi Surdud and interstratified within an alluvial sedimentary basin in the foothills that connect the Yemeni highlands with the Tihama coastal plain. A number of environmental proxies indicate arid conditions throughout a sequence that extends between 63 and $42 \mathrm{ka}$ BP. The lithic industry is geared toward the production of a variety of end products: blades, pointed blades, pointed flakes and Levallois-like flakes with long unmodified cutting edges, made from locally available rhyolite. The occasional exploitation of other local raw materials, that fulfill distinct complementary needs, highlights the multi-functional nature of the occupation. The slightly younger Shi'bat Dihya 2 (SD2) site is characterized by a less elaborate production of flakes, together with some elements (blades and pointed flakes) similar to those found at SD1, and may indicate a cultural continuity between the two sites. The technological behaviors of the SD1 toolmakers present similarities with those documented from a number of nearly contemporaneous assemblages from southern Arabia, the Levant, the Horn of Africa and North Africa. However, they do not directly conform to any of the techno-complexes typical of the late Middle Paleolithic or late Middle Stone Age from these regions. This period would have witnessed the development of local Middle Paleolithic traditions in the Arabian Peninsula, which suggests more complex settlement dynamics and possible population interactions than commonly inferred by the current models of modern human expansion out of Africa.
\end{abstract}

(c) 2012 Elsevier Ltd. All rights reserved.

\footnotetext{
* Corresponding author.

E-mail address: a.delagnes@pacea.u-bordeaux1.fr (A. Delagnes).

$\dagger$ This work is dedicated to our late and greatly missed colleague and friend, Mohammad Al-Halibi.
}

\section{Introduction}

The expansion of modern humans out of Africa and into Eurasia via the Arabian Peninsula is currently one of the most debated questions in prehistory (Petraglia and Rose, 2009; Petraglia, 2011). The most frequently advanced evidence is from analyses of the human genome, which suggests the expansion of a branch of Homo sapiens from East Africa around $60 \mathrm{ka}$ BP (thousands of years ago 
before present) (e.g., Quintana-Murci et al., 1999; Forster and Matsumura, 2005; Macaulay et al., 2005; Fagundes et al., 2007; Campbell and Tishkoff, 2008; Li et al., 2008; Chiaroni et al., 2009; Deshpande et al., 2009; Tishkoff et al., 2009; Scheinfeldt et al., 2010). This "Out of Africa 3" model (Klein, 2008) also seems supported by patterns of worldwide craniometric variation (Manica et al., 2007). The Arabian Peninsula is routinely considered as the corridor where migrating East African populations would have passed during a single or multiple dispersal events (Clark, 1989; Lahr and Foley, 1994, 1998; Stringer, 2000; Derricourt, 2005; Beyin, 2006; Mellars, 2006a, 2006b; Rose, 2007a; Marks, 2008; Shea, 2008; Petraglia, 2011). These episodes of demographic expansion are thought to correspond with wet phases, whereas Arabia would have been deserted during arid and hyper-arid events (Rose, 2004b; Petraglia, 2005; Rose, 2007b; Carto et al., 2009; Parker, 2009). This seems at odds with the fact that during Pleistocene glacial maxima, correlated with periods of Red Sea level lowstand, narrow channels less than 4-5 km wide would have favored sea crossings between Africa and southern Arabia (Winney et al., 2004; Lambeck et al., 2011; but see; Fernandes et al., 2006). It has also been suggested that the groups who colonized South Asia rapidly expanded from South and East Africa along the Arabian coastlines around $60 \mathrm{ka} \mathrm{BP}$, bringing with them a modern behavioral package including microlithic backed tools, ostrich-eggshell beads or engraved fragments (Mellars, 2006a). However, this scenario is not supported by any 'hard' archaeological evidence from the Arabian Peninsula. Up until recently, the absence of stratified contexts from the entirety of the region has rendered issues concerning the timing and trajectories of the earliest expansions of modern humans into the region largely theoretical.

A set of recently investigated archaeological sites or complexes of sites in stratified contexts bring new insights to this debate. It suggests that a major phase of human expansion into Arabia occurred much earlier than $60 \mathrm{ka}$ BP, during MIS 5. Related assemblages have been found at Jebel Faya in the United Arab Emirates (Armitage et al., 2011), in the Dhofar region of Oman (Rose et al., 2011), in the Nefud desert of Saudi Arabia (Petraglia et al., 2011). They date to the beginning of MIS 5 (Jebel Faya, assemblage $C$ and Nubian complex sites from the Dhofar region) or MIS 5a (Jubbah basin sites in the Nefud desert). Both periods correspond to humid phases that were favorable to faunal and human range expansion (Fernandes, 2009; Petraglia, 2011). These assemblages have been assigned to an Middle Stone Age (MSA) - like industry (Jebel Faya, assemblage C), the Nubian Complex (Dhofar region) or to the Arabian Middle Paleolithic (Jubbah basin). The assemblages from the Dhofar region, as well as those from Jebel Faya (C), seem to reflect connections between Arabia and Africa during early MIS 5. While no human fossils have yet been recovered from any of these contexts, it has been proposed that the groups responsible for these industries were modern humans, having dispersed into Arabia much earlier than previously assumed, between 120 and $80 \mathrm{ka}$ (Armitage et al., 2011; Rose et al., 2011).

This new scenario raises a series of questions: which populations are responsible for the lithic assemblages present in Arabia around 60-50 ka and what types of settlement dynamics may be inferred from the available data? Here we report preliminary evidence from a Middle Paleolithic site complex recently documented in the Wadi Surdud basin of western Yemen and dated to between 60 and $50 \mathrm{ka}$ BP. It represents the first stratified and dated Middle Paleolithic site complex in this part of the Arabian Peninsula that directly faces East Africa. It also forms a unique occurrence in Arabia during this period that apparently witnessed a considerable expansion of modern humans across Eurasia. So far, evidence for an MIS 3 expansion event is totally absent from the Arabian archaeological record. Furthermore, our data from the Wadi Surdud region points to a new scenario where local populations persisted in Arabia throughout the arid phases of MIS 3 and developed their own Middle Paleolithic tradition. We present the geographic setting and environmental context of the Wadi Surdud basin, OSL dates from the entire stratigraphic sequence, and a detailed archaeological and technological analysis of the material from the main site investigated so far, Shi'bat Dihya 1 (SD1), whose lithic assemblage is then compared with preliminary evidence available from the younger Shi'bat Dihya 2 (SD2) site.

\section{Geography, chrono-stratigraphy and paleo-environments of the Wadi Surdud site complex}

The Wadi Surdud sedimentary basin is situated in the western Yemeni region of Al-Mahqwit, along the route connecting Sana'a and Al-Hodeidah, near the village of Khamis Bani Saad (Fig. 1). The Wadi Surdud cuts through the foothills of the western Yemeni highlands and empties into the Tihama coastal plain some $50 \mathrm{~km}$ from the present shores of the Red Sea. To the west, the Tihama coastal plain is a flat sandy and hyper-arid area, which stretches along the Yemeni Red Sea coast from the Bab-al-Mandab strait to the Saudi Arabian border. The western escarpment of the Yemeni highlands that border the basin to the east is a jagged mountain range, which rises to a maximum altitude of $3760 \mathrm{~m}$ above sea level (asl), with annual rainfall levels increasing (up to $1000 \mathrm{~mm}$ ) gradually with altitude. The foothills form an intermediate topographic and climatic zone between these two highly contrasting eco-systems.

The Wadi Surdud archaeological complex in western Yemen, first discovered in late 2005 during surveys carried out by the international Paleo-Y project (Macchiarelli, 2009), consists of a series of stratified sites on the left bank of the Wadi Surdud at an average altitude of $365 \mathrm{~m}$ (asl). The archaeological remains were visible in the natural sections formed by the ephemeral streams of the Shi'bat Dihya and Shi'bat al-Sharj which are tributaries of the Wadi Surdud. The first site identified, Shi'bat Dihya $1\left(15^{\circ} 11.371 \mathrm{~N}\right.$, $43^{\circ} 25.670 \mathrm{E}$ ), was excavated in 2006 and 2008. Several other sites are stratified within the same sedimentary unit (Shi'bat Dihya Member; Fig. 2). These include Shi'bat Dihya 2 (SD2), located on the opposite bank of Shi'bat Dihya, some $100 \mathrm{~m}$ south of SD1 and some $7 \mathrm{~m}$ above stratigraphically, and Al-Sharj 1 (AS1), some $6 \mathrm{~m}$ above SD2 in stratigraphy and approximately $400 \mathrm{~m}$ to the west along Shi'bat Al-Sharj, which runs parallel to Shi'bat Dihya. Chronostratigraphically, SD1 is thus slightly older than SD2, while the latter is still earlier than AS1 (Fig. 2).

The Middle Paleolithic archaeological sites are preserved within a sedimentary sequence essentially composed of sands and silts, representing the infilling of a small Quaternary piedmont basin cut by the Wadi Surdud. Two main alluvial units have been identified: the lower one, called Al-Sharj Member, although largely eroded, has yielded a few scattered artifacts. The overlying sedimentary unit, or Shi'bat Dihya Member (Fig. 2), has truncated this lower unit and still retains a significant volume of sediments. Three main archaeological sites have been recovered so far in the Shi'bat Dihya Member (SD1, SD2 and AS1) (Fig. 2). Overall the Shi'bat Dihya Member is approximately $30 \mathrm{~m}$ thick and results from low-energy overbank sedimentation of a floodplain. The predominantly silty sediments are thought to derive from the remobilization of loessic material from the coastal sand desert within the wadi.

The absence of a paleosol visible in the stream sections is consistent with the absence of botanical remains (i.e., phytoliths) across the entire sequence (Messager, pers. comm.), together with a very low organic content of the sediments (organic carbon $=0.03-0.04 \% \mathrm{wt}$; Hatté, pers. comm.). This indicates the rapid accretion of the floodplain and/or that environmental conditions were not favorable to the development of vegetation. Calcrete horizons identified in the 

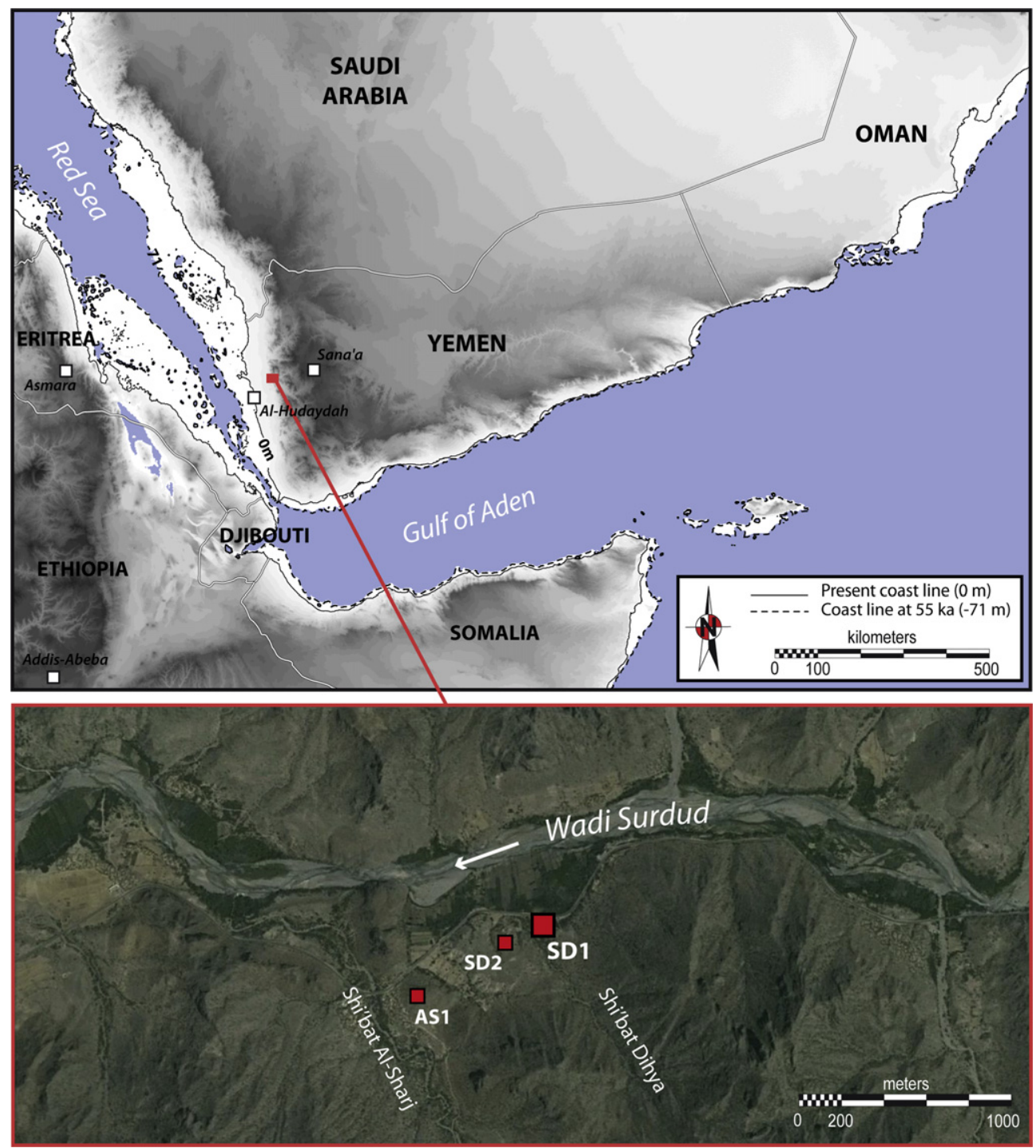

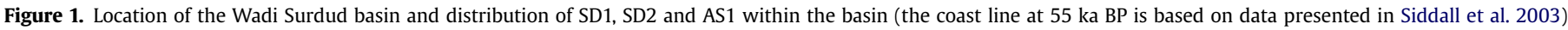

stratigraphy represent reference levels that could be traced from one section to another across the entire basin. The analysis of thinsections indicates that these calcretes derive from the precipitation of groundwater carbonates as a consequence of significant evaporation. Secondary precipitations of gypsum are also present throughout the sequence. Given the absence of potential gypsum sources in the catchment area of the wadi, its presence is probably connected to windblown sediments containing calcium ions and sulfates from the coastal sebkhas. Both gypsum and groundwater calcretes indicate that the environment contemporaneous with the human occupation was semi-arid to arid. However, these conditions do not correspond to the driest periods of the last Upper Pleistocene climatic cycle in the Arabian Peninsula. The Shi'bat Dihya alluvial formation was deposited at the beginning of MIS 3, and corresponds to a phase where the influence of the Indian summer monsoon had strengthened (Clemens and Prell, 2003; Leuschner and Sirocko, 2003).

The chronology of the Wadi Surdud sequence was established by way of 19 Optically Stimulated Luminescence (OSL) dates on sediment samples (Aitken, 1998; Lian and Roberts, 2006) (for more details on the dating protocols, see Supplementary Online Material). Except for the uppermost sample (AS1-08/OSL2) dated to $42 \pm 4 \mathrm{ka}$ and the lowest sample (AS2-08/OSL20b) from the underlying sedimentary Al-Sharj Member (Fig. 3), where occasional pieces were found in situ, that produced a date of $84 \pm 10 \mathrm{ka}$, all optical ages are consistent at one or two sigma with a mean age of $55 \mathrm{ka}$ (i.e., the chronostratigraphic inversions are not significant). This suggests that the interval of time during which the Shi'bat Dihya Member was deposited is inferior or equal to the error margin $(<10 \mathrm{ka})$. A tephra sample from SD2 was also dated using the $40 \mathrm{Ar}-39 \mathrm{Ar}$ method. Its age determination $(269 \pm 19 \mathrm{Ma})$ is well beyond the true age of deposit and is most likely due to the presence of old xenocrysts from the Precambrian basement. The very fine grain-size (below $100 \mu \mathrm{m}$ ) of the tephra layer did not allow to separate the xenocrystic component from the primary crystals.

\section{Materials and methods}

The exposure and excavation of a $21 \mathrm{~m}^{2}$ archaeological layer at SD1 was carried out over two field seasons. This surface corresponds to the western-most extremity of a horizon oriented east to west with a maximum thickness of $15 \mathrm{~cm}$. Although its total surface area is yet to be determined, this level could extend over several hundred square meters given that lithic artifacts were recovered along a substantial portion of the natural cut that forms the 


\section{Northern bank of Shi'bat Dihya gully}

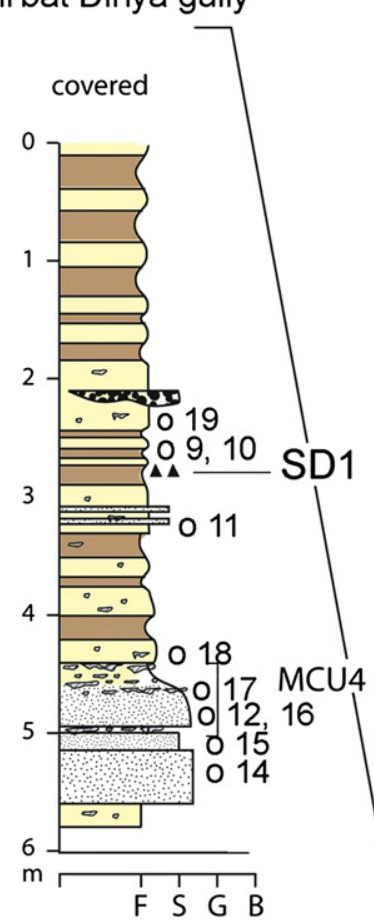

\footnotetext{
O OSL sample

calcrete

pale brown clay

pale yellow silt

pink silt

sand

[5. angular slope-derived gravel

rounded alluvial blocks and gravel

$\Delta \mathbf{\Delta}$ artifacts

MCU main calcrete units
}

\section{Southern bank of Shi'bat Dihya gully}

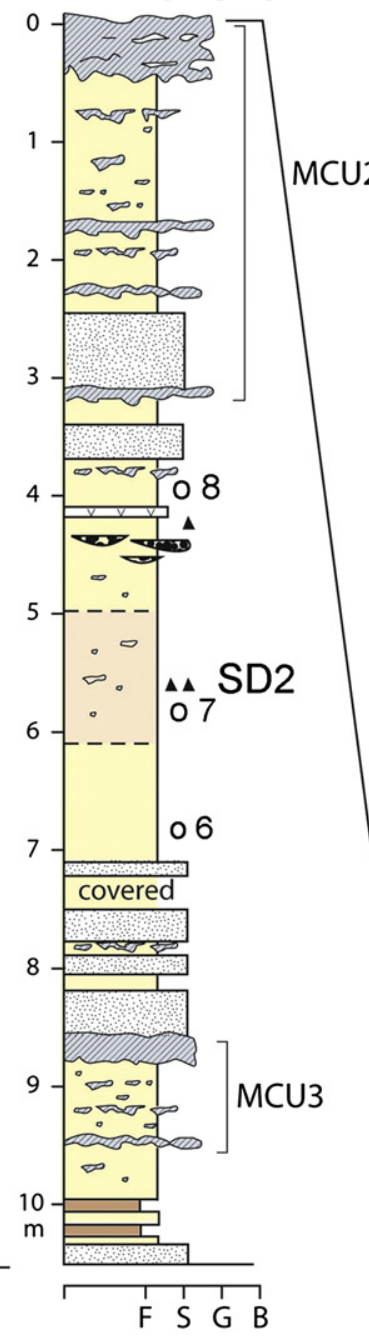

Northern bank of

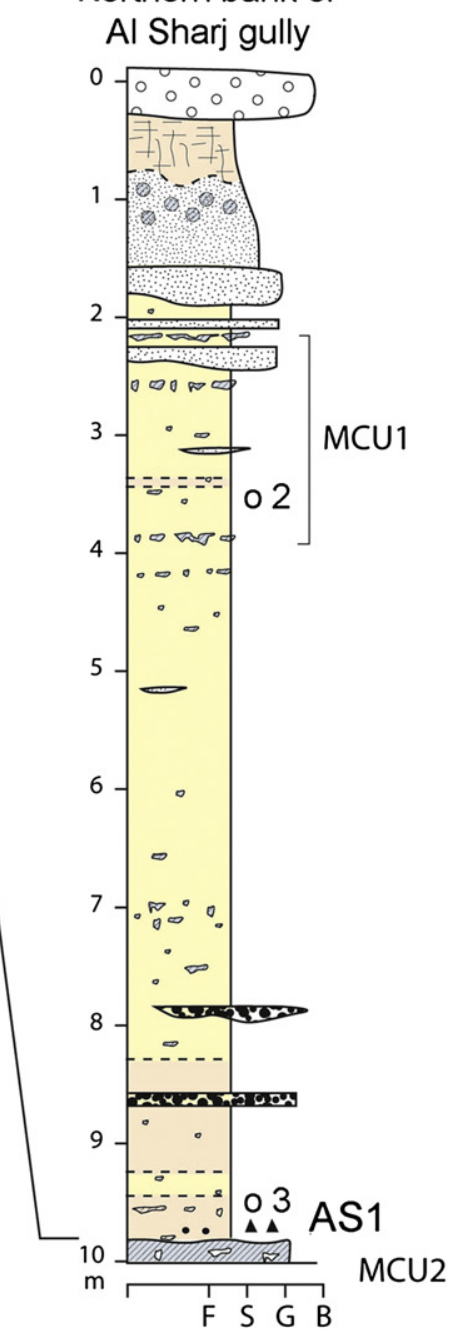

F:fines, S: sand, G: gravel, B: boulder

Figure 2. Synthetic stratigraphic log of Shi'bat Dihya member, which includes SD1, SD2 and AS1 archaeological sites.

northern border of the site. The site's western limit has been eroded by a ravine incised by the small, now dried out stream of Shi'bat Silhya. Based on the material visible in the section, the excavated sector corresponds to the most archaeologically dense zone. All lithic remains greater than $2 \mathrm{~cm}$, as well as all determinable and indeterminable faunal remains, were plotted in three dimensions. Lithic and unidentifiable faunal elements less than $2 \mathrm{~cm}$ were recovered during wet sieving $(2 \mathrm{~mm}$ mesh) and can be tied to $25 \mathrm{~cm}^{2}$ sub-squares. The recovered archaeological assemblage consists of 5,488 artifacts with maximum dimensions equal to or greater than $2 \mathrm{~cm}$, nearly 25,000 lithic remains less than $2 \mathrm{~cm}(82 \%$ of the assemblage), and 97 faunal fragments identified both anatomically and taxonomically. All of the lithic artifacts greater than $2 \mathrm{~cm}$ were individually studied and recorded in a database with a number of petrographic, dimensional and technological attributes. Several series of lithic refits, comprising 135 pieces $(2.7 \%$ of all pieces in rhyolite), result from limited refitting tests, which focused on only seven worked blocks that were easily discernible based on their particular physical properties (color, grain, cortex).

While the lithic industry from SD1 is sufficiently representative to allow a detailed study, archaeological investigations run so far at both SD2 and AS1 have only provided an initial sample of their 


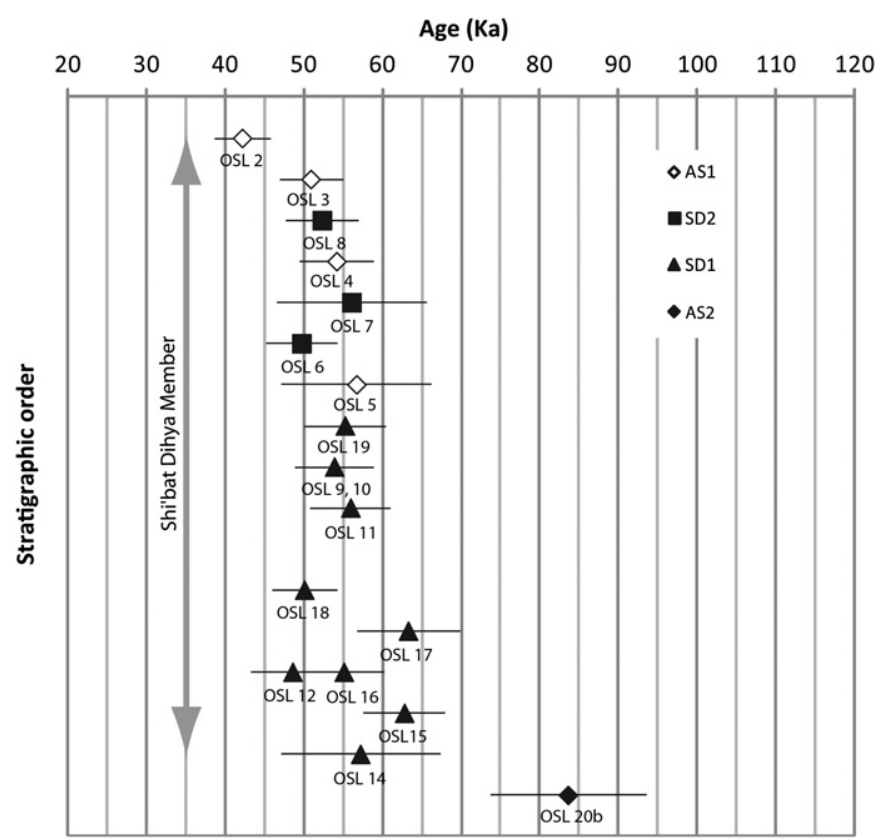

Figure 3. Optical ages of all samples from the Wadi Surdud sequence in stratigraphic order.

lithic industries, given the small size of the excavated areas (for SD2, cleaning of the section). Only the sample from SD2 is large enough for a preliminary comparative analysis with SD1.

\section{Results}

\section{Material preservation at SD1 and site spatial configuration}

The lithic artifacts recovered from SD1 form a homogeneous assemblage, both technologically and in terms of their preservation. They include products and sub-products (Table 1) of a chaîne opératoire geared toward the production of predominantly triangular or pointed flakes and blades. All of the exploited raw materials, of which rhyolite dominates, are easily and abundantly accessible in the immediate alluvial deposits as well as in the paleobeds of alluvial gravels interstratified within the underlying AlSharj sedimentary unit. Retouched tools are rare, uncharacteristic, and are accompanied by the occasional pebble tool. The preservation of the material is uniform and generally very good. Apart from occasional impact damage, the edges are very fresh and present no traces of abrasion. Furthermore, the assemblage is sufficiently sizable to permit a detailed technological analysis.

The original spatial distribution of the lithics is partially detectable given the existence of artifact concentrations representing the clustered debitage of a singular block of raw material. This preservation can be attributed to the rapid burial of the archaeological horizon in a context of overbank floodplain deposit. However, the remobilization of the archaeological remains after their deposition certainly occurred, as evidenced by the undulating profile of the upper part of the archaeological horizon, resulting from flooding and deflooding processes.

A significant portion of the faunal assemblage $(n=42 / 97)$ consists of very poorly preserved (friable and severely altered) postcranial fragments whose anatomical or taxonomic assessment is impossible. However, complete and fragmented teeth can be assigned to Bovidae ( $n=12 / 97)$, Equidae $(n=9 / 97)$, Suidae $(n=9 / 97)$ and Hystricidae ( $n=3 / 97$ ), with the remaining 22 fragments being unidentifiable. Among the equid remains, the presence of a complete M3 assigned to Equus sp. cf. Equus hemionus is noteworthy as it is a taxon characteristic of arid steppe environments and that no longer inhabits the Arabian Peninsula (Reading et al., 2001).

Poor surface conservation of the bone fragments did not allow for the identification of cut marks or other traces of human intervention. Vertical projections of the faunal remains (Fig. 4) do, however, indicate them to be contemporaneous with the human occupation, as they are distributed throughout the archaeological deposit and follow the same undulating profile. Furthermore, the rapid burial of the archaeological remains after their deposition, together with the absence of faunal fragments in the deposits bordering the site, confirms that lithic and faunal remains are primarily associated within the deposit. No evidence of symbolic activity (pigments, ornaments, etc.) was recovered.

\section{Raw material procurement and exploitation at SD1}

The raw materials exploited by the occupants of SD1 derive from the Tertiary volcanic deposits that essentially compose the relief of the local landscape, from the Precambrian basement, and from the Cretaceous sandstones that outcrop along the northern bank of the Wadi Surdud itself. The paleo-channels accessible to the occupants of SD1, especially in the underlying terrace, remain to be determined. These different materials are abundantly available in the local alluvial deposits. The Wadi Surdud, which spreads across

Table 1

Composition of the SD1 lithic assemblage (blocks 1, 2, 4 correspond to three distinct and partially refitted knapped pebbles).

\begin{tabular}{|c|c|c|c|c|c|c|c|}
\hline$N$ & All materials & Rhyolite & $\begin{array}{l}\text { Whole } \\
\text { products }\end{array}$ & $\begin{array}{l}\text { Retouched } \\
\text { tools }\end{array}$ & Block 1 (refits $1-5$ ) & $\begin{array}{c}\text { Block 2 } \\
\text { (refits } 43-45-46)\end{array}$ & Block 4 (refits 22) \\
\hline Whole pebbles & 8 & 1 & - & - & $0(0-0)$ & $0(0-0-0)$ & $0(0)$ \\
\hline Worked pebbles & 5 & 1 & - & - & $0(0-0)$ & $0(0-0-0)$ & $0(0)$ \\
\hline Hammerstone fragments & 8 & 0 & - & - & $0(0-0)$ & $0(0-0-0)$ & $3(0)$ \\
\hline Cortical flakes & 763 & 682 & 516 & 4 & $9(0-3)$ & $2(1-0-0)$ & $1(0)$ \\
\hline Cortical backed flakes & 233 & 196 & 165 & 3 & $9(2-2)$ & $2(0-0-0)$ & $0(0)$ \\
\hline Undifferenciated flakes & 1,821 & 1,699 & 1,297 & 5 & $26(7-4)$ & $9(1-0-1)$ & $0(0)$ \\
\hline Kombewa flakes & 100 & 95 & 69 & 0 & $2(0-0)$ & $1(1-0-0)$ & $2(1)$ \\
\hline Pointed flakes & 716 & 709 & 600 & 3 & $9(2-0)$ & $9(0-4-4)$ & $0(0)$ \\
\hline Levallois-like flakes & 310 & 293 & 157 & 0 & $4(0-2)$ & $5(0-0-0)$ & $8(6)$ \\
\hline Blades & 686 & 676 & 485 & 7 & $8(3-0)$ & $7(2-2-1)$ & $1(0)$ \\
\hline Pointed blades & 164 & 164 & 114 & 3 & $3(3-0)$ & $3(0-1-1)$ & $0(0)$ \\
\hline Blade cores & 10 & 10 & - & 0 & $0(0-0)$ & $1(1-0-0)$ & $0(0)$ \\
\hline Point cores & 12 & 12 & - & 0 & $0(0-0)$ & $0(0-0-0)$ & $0(0)$ \\
\hline Levallois-like cores & 6 & 6 & - & 0 & $0(0-0)$ & $0(0-0-0)$ & $0(0)$ \\
\hline Undiff. cores and core fragments & 11 & 10 & - & 0 & $0(0-0)$ & $0(0-0-0)$ & $0(0)$ \\
\hline Fragments and debris & 623 & 379 & - & 0 & $11(0-0)$ & $2(0-0-0)$ & $0(0)$ \\
\hline Total $>2 \mathrm{~cm}$ & 5,488 & 4,933 & 3,403 & 25 & $81(17-11)$ & $41(6-7-7)$ & $15(7)$ \\
\hline
\end{tabular}


A

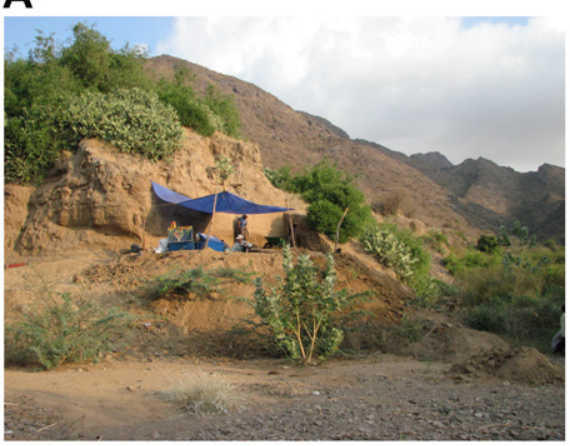

B

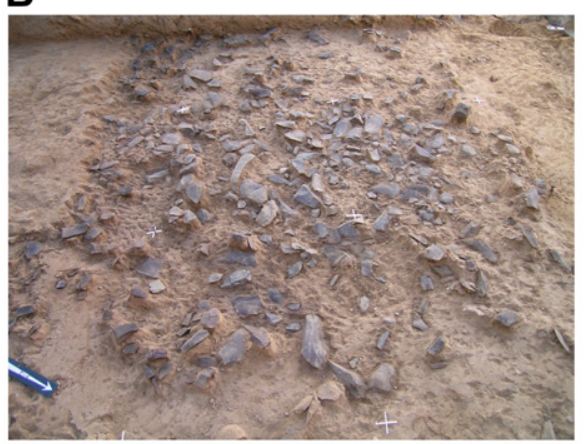

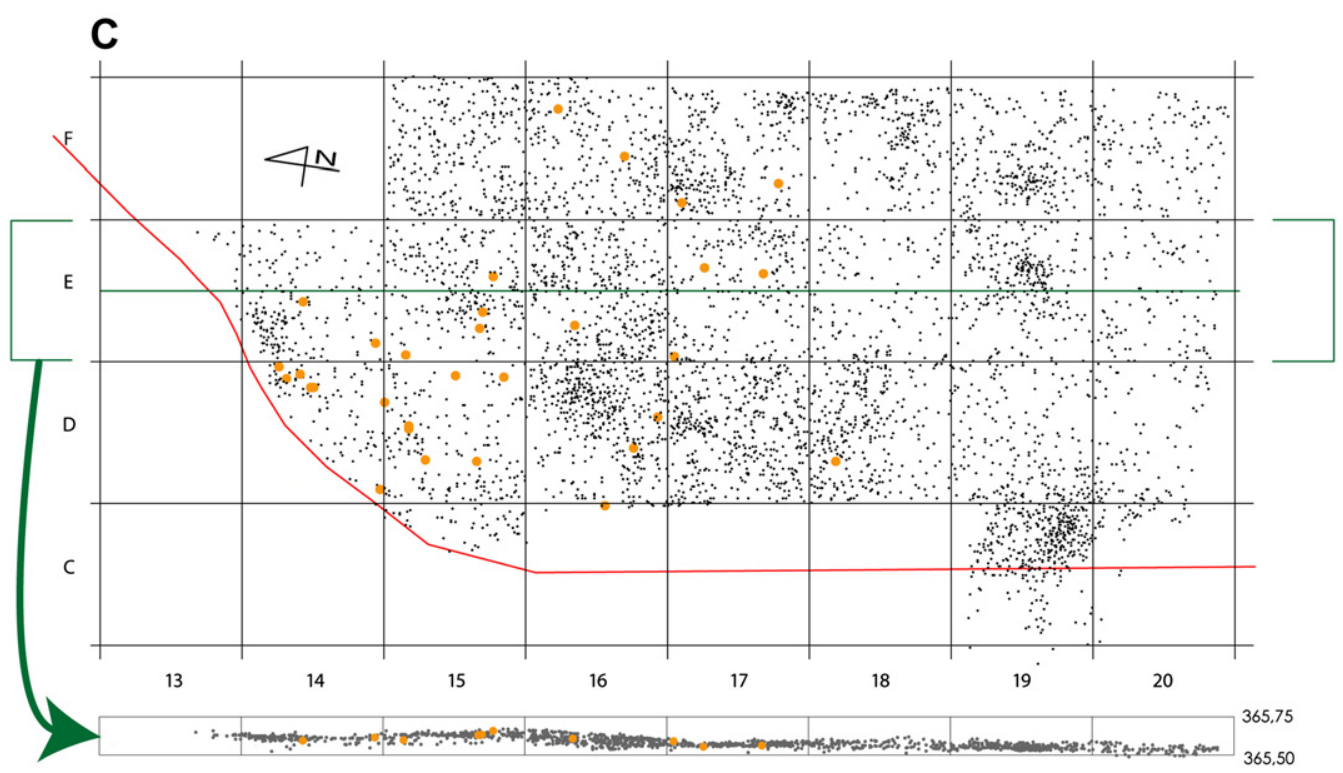

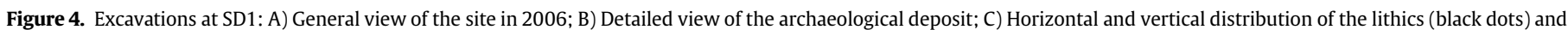
bone/tooth fragments (orange dots) (For interpretation of the references to color in this figure legend, the reader is referred to the web version of this article.).

a large (100-200 m) gently sloping alluvial plain, drains material that is mostly spherical or has rounded edges, whereas the narrow and steep tributaries that drain the runoff of torrential storm waters into the wadi, such as Shi'bat Dihya and Shi'bat Al-Sharj, contain angular blocks with fresh ridges or ridges blunted by numerous impacts. The occupants of SD1 preferentially selected materials from these latter sources.

The raw materials constitute five main groups: rhyolite (93.8\%), basalt (2.4\%), phonolite (1.8\%), quartz (1.7\%) and sandstone $(0.3 \%)$. Given that rhyolite represents a high-quality material that is both fine-grained and homogeneous, it is not surprising that it dominates the assemblage. Our experimental tests demonstrate that this material, despite being somewhat difficult to fracture, is perfectly amenable to hard-hammer percussion and was certainly preferentially collected. Rhyolite was employed exclusively for the production of flakes and blades by way of relatively simple reduction strategies that nonetheless required a high level of both technical ability and an understanding of the mechanical properties of the material. This material demands powerful blows and therefore is not compatible with elaborate platform preparation such as faceting. The technological composition of the other materials confirm that they fulfilled very specific and complementary needs (Fig. 5).

Basalt The majority of unworked, broken, or worked pebbles in the assemblage are in basalt $(n=9 / 13)$. This material is represented in particular by two chopper-cores in green basalt, which share very similar dimensions as well as morphological and petrographic characteristics (Fig. 6). These items may in fact be multipurpose pieces representing both heavy duty tools and unidirectional cores.

Other worked pebbles correspond undoubtedly to cores, with striking angles often around $90^{\circ}$, suggesting debitage by bipolar percussion (Mourre, 2004). A fragment of a basalt hammer with percussion impacts that produced two unintentional removals under $9 \mathrm{~cm}$ in length was also recovered. The majority of flakes $(54 \%, n=55)$ are cortical with lengths that vary between 3 and $8 \mathrm{~cm}$ and demonstrate unidirectional scar negatives, cortical butts, and lateral or lateral-distal margins often bearing cortex. Smaller undifferentiated flakes ( $n=34 / 98,33 \%)$ also have cortical butts, confirming that they were produced exclusively from natural surfaces. These pieces directly correspond with the negatives still visible on the choppers-cores. Rare non-cortical flakes (7\%, $n=7$ ) and blades $(2 \%, n=2)$ could testify to a more elaborate debitage of this material.

The exploitation of basalt pebbles is clearly distinguished from the other materials exploited at the site by a simple debitage that generated unidirectional products from natural surfaces during short reduction sequences. The density of this material made it also particularly well-adapted to the fabrication of chopper-tools, which probably functioned as heavy duty tools.

Quartz The majority of these artifacts are made from cryptocrystalline quartz in the form of rounded pebbles, bearing a neocortex indicative of substantial fluviatile transport characteristic of the Wadi Surdud alluvia. The assemblage includes one 


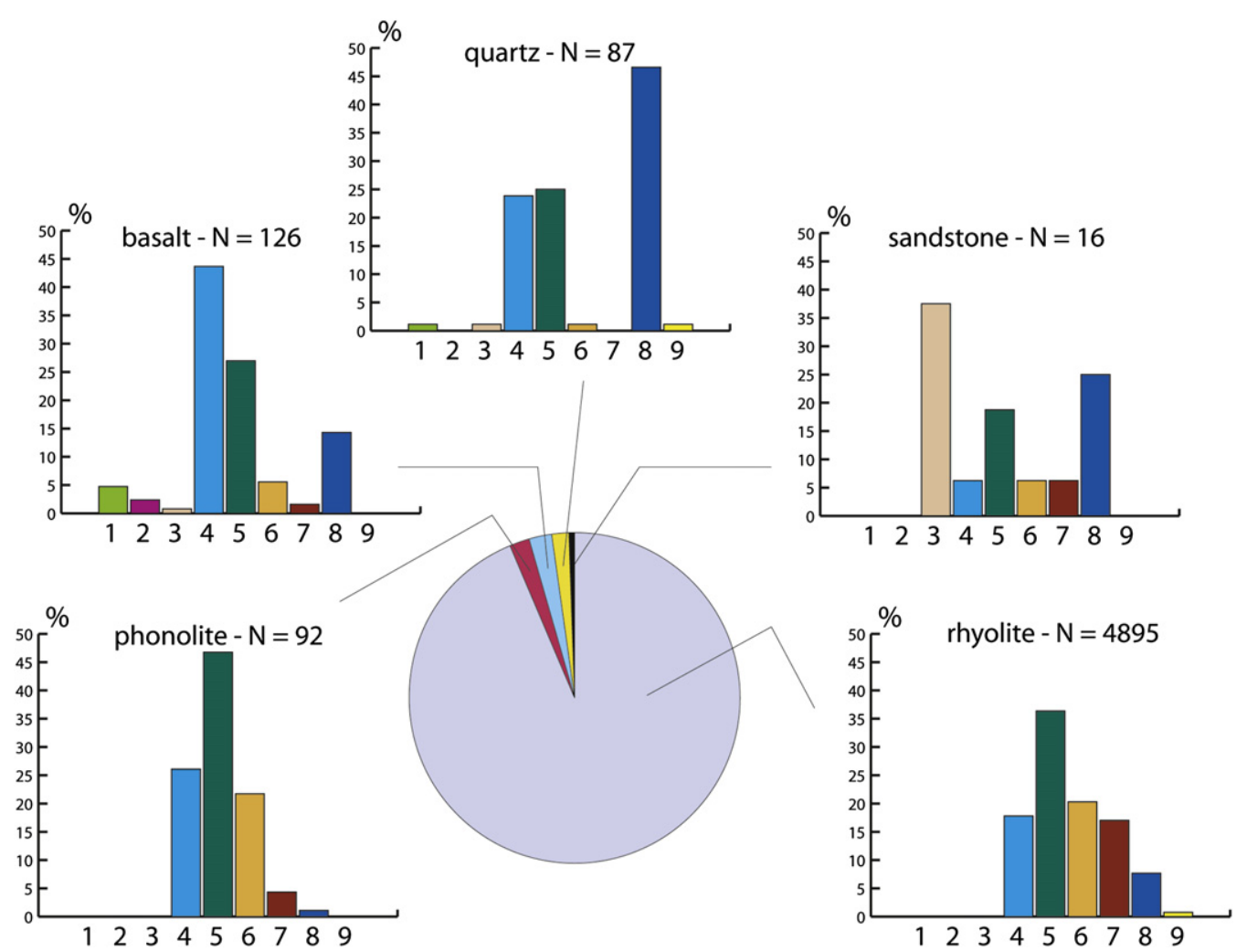

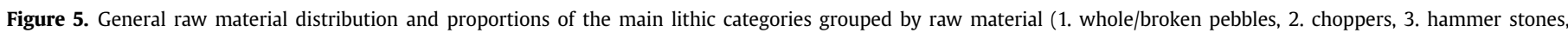
4. cortical flakes, 5. indeterminate flakes, 6. Levallois-like flakes and points, 7. blades and pointed blades, 8. debris, 9. cores).
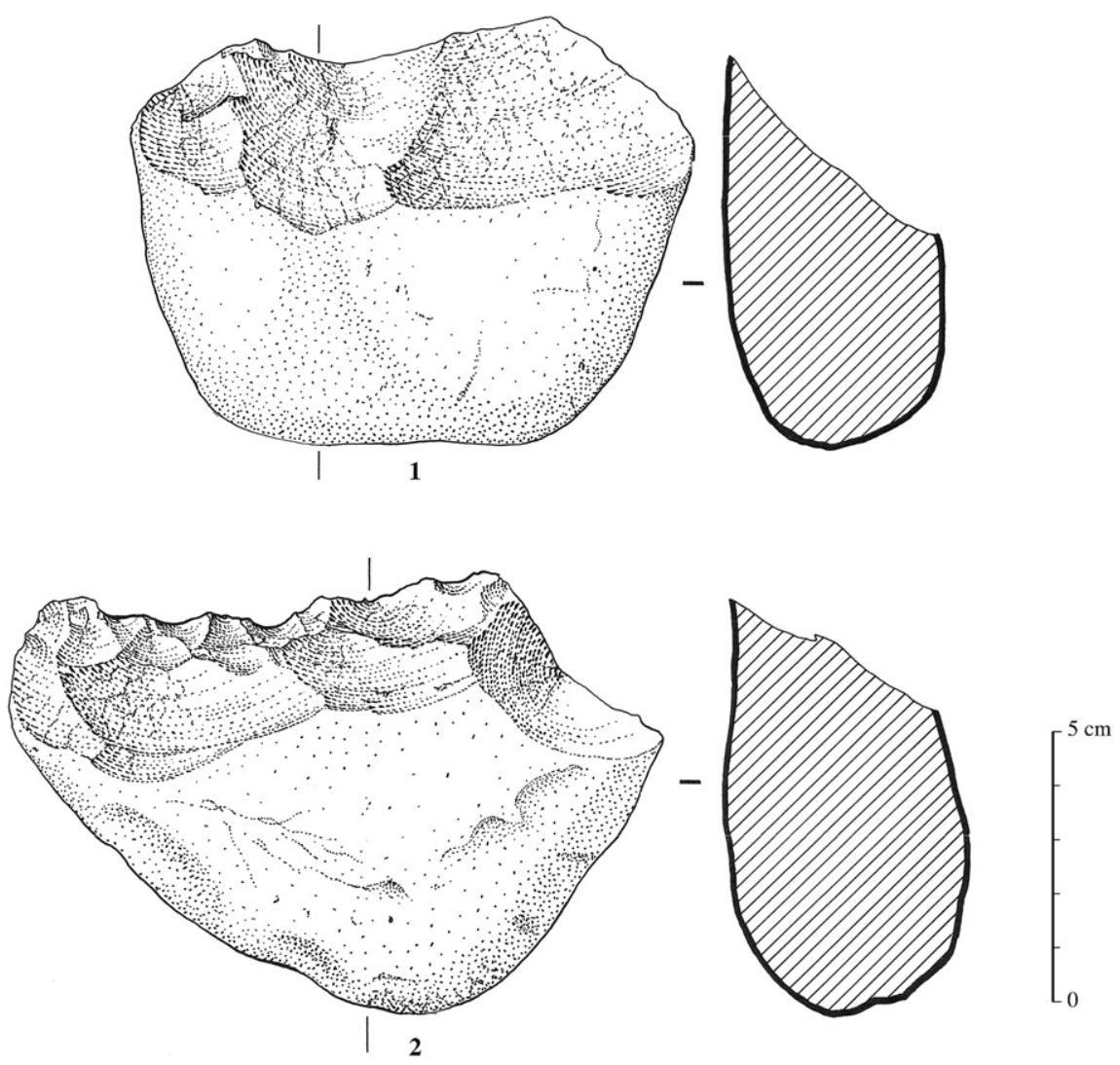

Figure 6. SD1 basalt chopper-cores. 

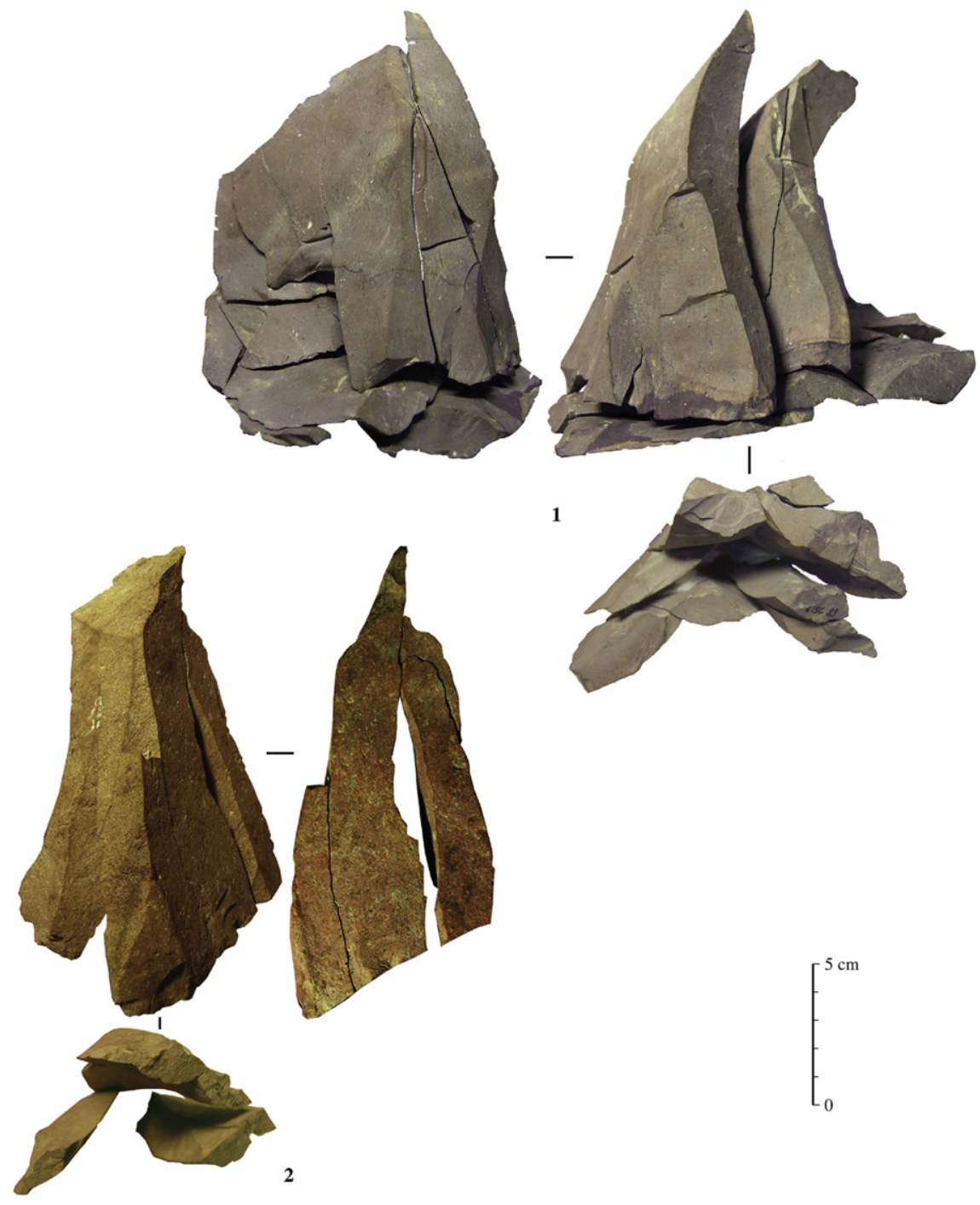

Figure 7. Partial refits of two rhyolite blocks $(1,2)$ exploited according to a semi-tournant laminar debitage.

core of modest dimensions ( $L=3.9 \mathrm{~cm}$ ), which bears several very wide negatives of secant flakes produced by a partially bifacial discoid method. A small series of flakes with cortical butts confirms the presence of intentional debitage. The butts of several flakes indicate a flaking angle (lower face/butt) approaching $90^{\circ}$ and may derive from bipolar percussion. There are no retouched tools in quartz or any sound evidence indicating quartz pebbles having been used as hammers. Quartz was used for the informal production of flakes when compared with the main debitage sequences in rhyolite. The discoid method is common with this type of material (Mourre, 1996) and may have been accompanied by bipolar percussion.

Sandstone This raw material is represented by only 16 pieces issuing from four or five spherical pebbles, most likely collected from the bed of Wadi Surdud itself, including one small broken hammerstone $(5.5 \mathrm{~cm} \times 4.8 \mathrm{~cm})$ and five hammerstone fragments, of which two refit. All of them present a zone of percussion with numerous impact scars, while the remaining pieces (debris, undifferentiated and cortical flakes) seem to represent wasteproducts resulting from percussion and suggest that this material was almost exclusively used as hammerstone. Only two artifacts, a flake and a blade, could result from actual debitage.

Phonolite Although no cores were recovered, phonolite was flaked on-site. Debitage products mainly consist of undifferentiated (31\%, $n=34)$ and cortical flakes $(21 \%, n=23)$, several Levallois-like (see section 'Levallois production') flakes (15\%, $n=16$ ), and few blades $(4 \%, n=4)$. The sample is far too small for the reduction modes to be described in detail. Despite being coarser grained, the knapping quality of this material approximates that of rhyolite and it may have been exploited with similar objectives, complemented by a substantially less elaborate debitage method that produced undifferentiated flakes.

Rhyolite This is the most common material at SD1 and the only one that was exclusively exploited by way of elaborate debitage strategies. The abundance of products and sub-products permits a detailed technological study. Six main refits, comprising between six and 18 products, allow a direct, albeit partial, identification of the reduction sequences (Table 1, Figs. 7and 8).

The various debitage principles associated with the exploitation of rhyolite share a certain number of general technical traits:

- debitage was carried out exclusively by direct hard-hammer percussion;

- production was primarily geared toward obtaining relatively un-standardized pointed or elongated pointed pieces by convergent unidirectional removals;

- a substantial degree of technical flexibility prohibits the strict equation of a debitage mode with a specific type of end 

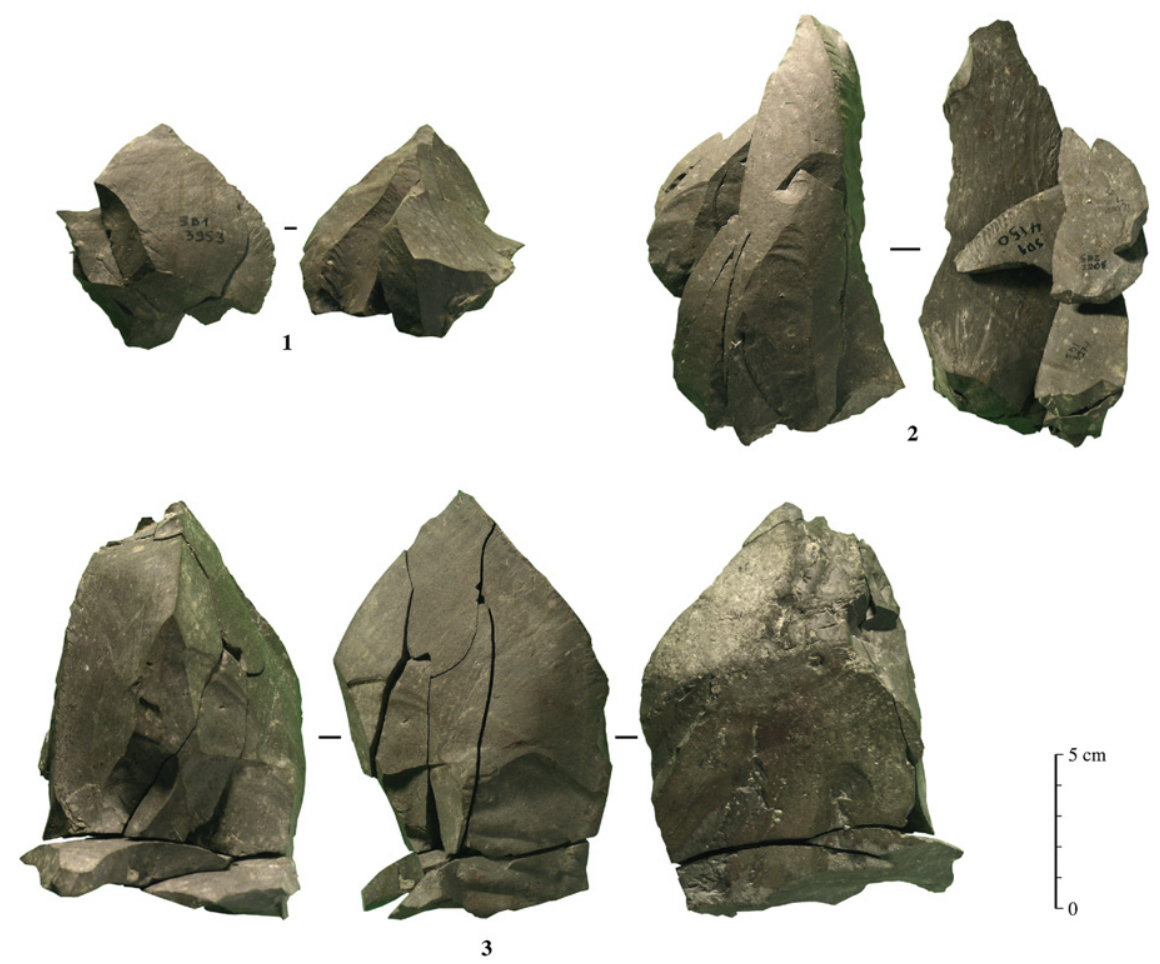

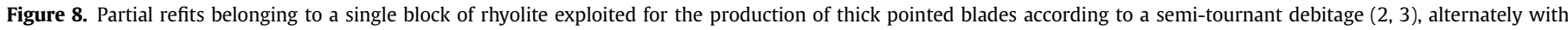
a debitage of pointed flakes (1).

product, in other words, each debitage principle produced a range of products that significantly overlap with those resulting from the others;

- core reduction involved a minimal number of technical gestures, especially in the preparation of the volumes and surfaces to be flaked. This was facilitated by the preferential selection and exploitation of blocks, fragments of blocks or even flakes whose rectilinear and angular edges were taken advantage of as guiding ridges for the initial removals. Striking platforms also show minimal and non-specific preparation (e.g., abrasion or faceting) for the removal of end products. This is evident in the dominance of plain striking platforms associated with all types of end products. Pointed flakes and Levallois-like flakes (see section 'Levallois production') only differ from laminar products (blades and pointed blades) by a slight increase in dihedral and faceted butts (Table 2).

\section{Rhyolite core reduction strategies at SD1}

Blade production It proceeded according to two principles of core volume management: a semi-tournant and a 'frontal' debitage strategy (Delagnes, 2000), both of which employed the thickness of very large flakes, blocks, or block fragments. The semi-tournant principle (Fig. 9) is documented by five refit sequences (Figs. 7 and 8 ) and a single associated core. Blades were extracted by unidirectional convergent removals that progressively expanded to adjacent faces, thus giving the core a semi-tournant front. The laminar debitage surface was not managed in the course of reduction, apart from the occasional partial crest. Striking platforms were prepared by multiple large removals. The production of pointed flakes, small points and pointed blades can be intercalated with the production of blades. The end products obtained (Fig. 9) are directly deduced from the refit sequences and comprise numerous forms (Fig. 9C, D, E): blades with thick cortical edges (Fig. 10: 1-4), large thick blades with triangular or trapezoidal sections (Fig. 10: 5-11), partially crested blades (Fig. 11: 1), small pointed blades (Fig. 11: 2-6), pointed flakes with one or two abrupt lateral edges bearing the negatives of previous laminar removals (Fig. 12: 14-18), and small non-Levallois points with maximum lengths of $2-3 \mathrm{~cm}$ (Fig. 13: $1-3$ ).

A second laminar reduction strategy, called 'frontal' debitage (Fig. 9), employs the thickness of flakes or flat blocks, making use of a ridge formed by the intersection of two surfaces (with an angle between $50^{\circ}$ and $70^{\circ}$ ) for the extraction of the opening blade (lame d'entame). The following removals are unidirectional and parallel, seldom bidirectional, and extend only slightly to the two adjacent surfaces, therefore rendering the laminar debitage surface only partially vaulted. The striking platform is most often prepared by way of a single removal creating a fairly restricted striking angle (between $65^{\circ}$ and $75^{\circ}$ ), which is amenable to tangential percussion. The laminar debitage surfaces do not seem to be managed in the course of reduction. The production sequences are of short to average length and produced anywhere between two and a dozen laminar products. This reduction strategy is illustrated by eight laminar or 'narrow-sided' cores (Monigal, 2001), for the most part on flakes (six of eight cores), with a maximum length of between 7 and $10 \mathrm{~cm}$ (Fig. 14: 1-4). Several cores present non-invasive, often hinged, laminar negatives of 'burin-like' removals.

Table 2

Platform types of the main categories of end products at SD1.

\begin{tabular}{lllll}
\hline$\%$ & Blades & Pointed blades & Pointed flakes & $\begin{array}{c}\text { Levallois-like } \\
\text { flakes }\end{array}$ \\
\hline Plain & 69.8 & 67.2 & 62.5 & 58 \\
Cortical & 3.3 & 6.0 & 3.7 & 8 \\
Dihedral & 9.8 & 7.8 & 17.5 & 18.1 \\
Faceted & 6.9 & 10.4 & 11.7 & 11.2 \\
Removed & 0.8 & 0.9 & 0.1 & 0 \\
Undet. & 8.4 & 6.0 & 3.1 & 3.4 \\
Punctiform & 1.0 & 1.7 & 1.4 & 1.3 \\
N Total & $\mathbf{5 1 0}$ & $\mathbf{1 1 6}$ & $\mathbf{6 5 6}$ & $\mathbf{3 7 6}$ \\
\hline
\end{tabular}




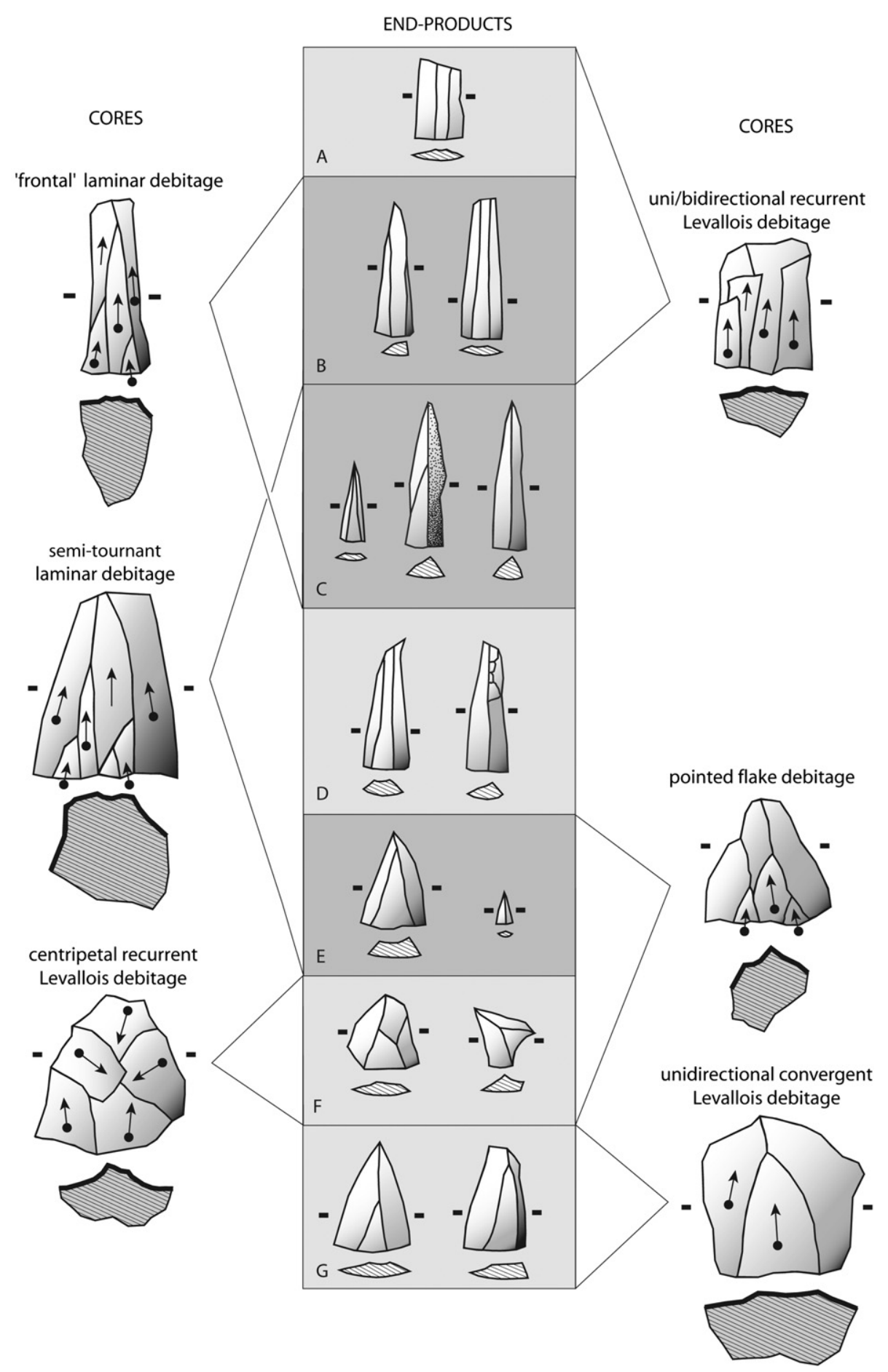

Figure 9. Principle core reduction strategies and related end products (A-G). (The bold line on the cores' section corresponds to the face of flake/blade extraction).

The resulting products correspond in part with those associated with the semi-tournant principle (Fig. 9B, C), in particular the ubiquitous initial cortical blades (Fig. 10: 1-4), the thick blades with triangular or trapezoidal sections (Fig. 10: 5-11), and the small pointed blades (Fig. 11: 2-6). On the other hand, some large blades are specific to these cores and can be differentiated by their generally rectilinear profiles and cross sections that are either asymmetrical, with a débordant lateral side (Fig. 11: 7), or symmetrical, but not very thick (Fig. 11: 8-10).

Production of pointed flakes It is attested to by a significant number of cores $(n=12)$ and pointed flakes $(n=655)$, thus conferring upon them an importance at least equivalent to that of blade production. The cores (Fig. 14: 5-8), with maximum lengths between 5 and $8 \mathrm{~cm}$, show no evidence of preparation prior to the extraction of pointed flakes. These pieces are produced from the intersection of two secant surfaces (forming a pronounced angle between $80^{\circ}$ and $100^{\circ}$ ) found on block fragments, debris, or trihedral flakes. Pointed flakes are thus characterized by two thick abrupt lateral planes, which give them a cross section clearly distinct from that of Levallois products. The striking platform is prepared by either a single large removal or a series of three to four smaller removals. The production sequences are 

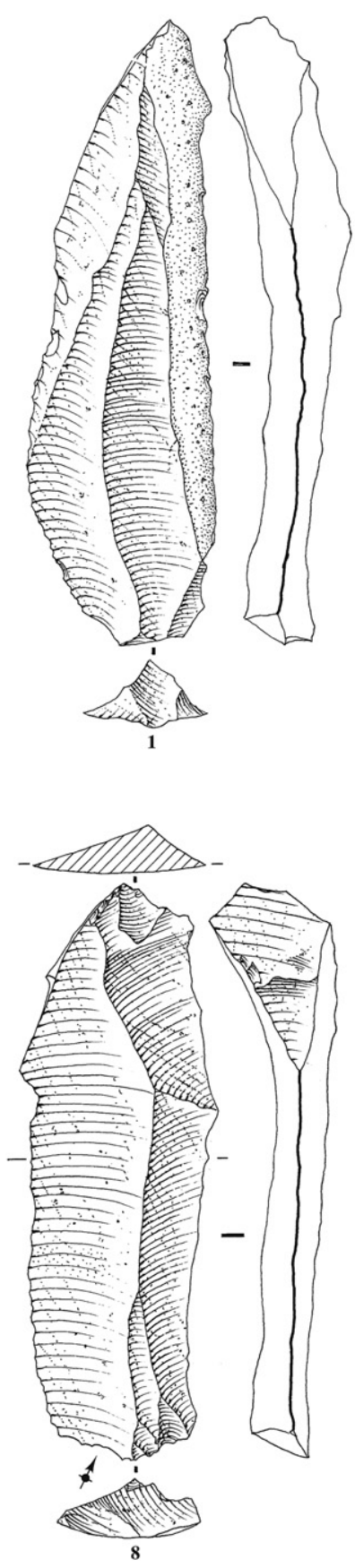
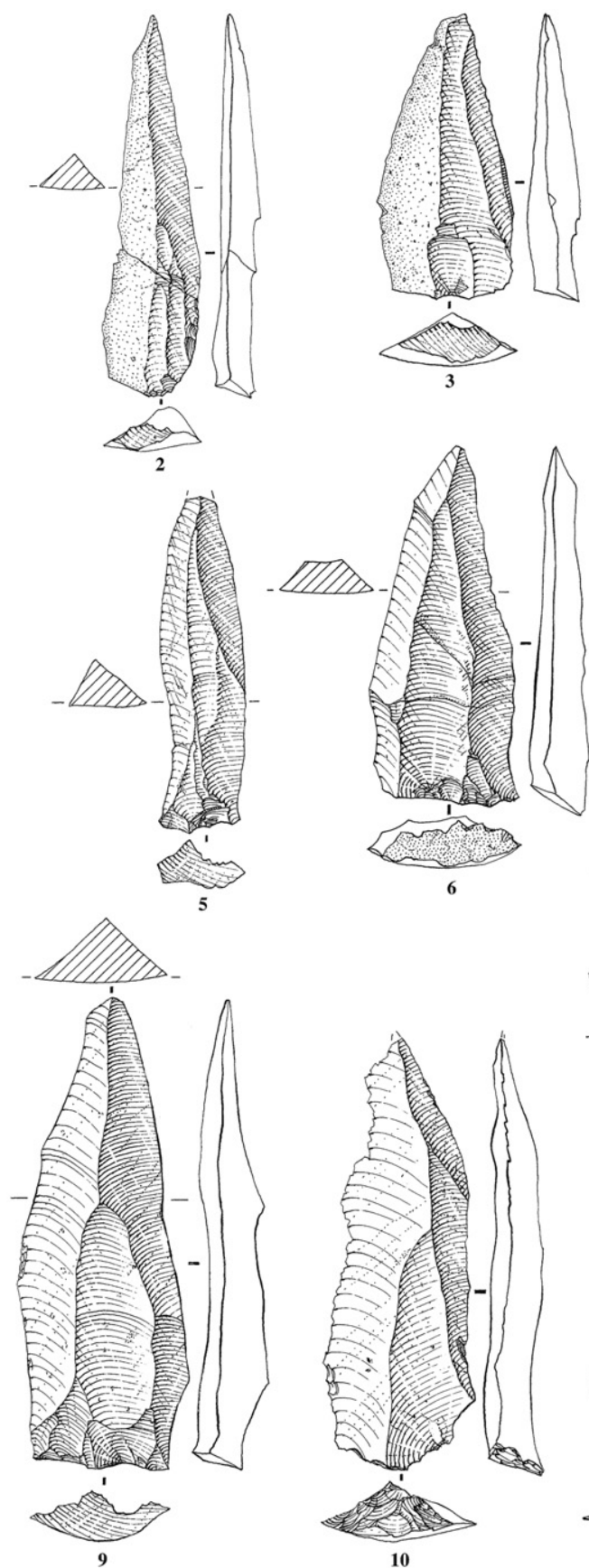

10
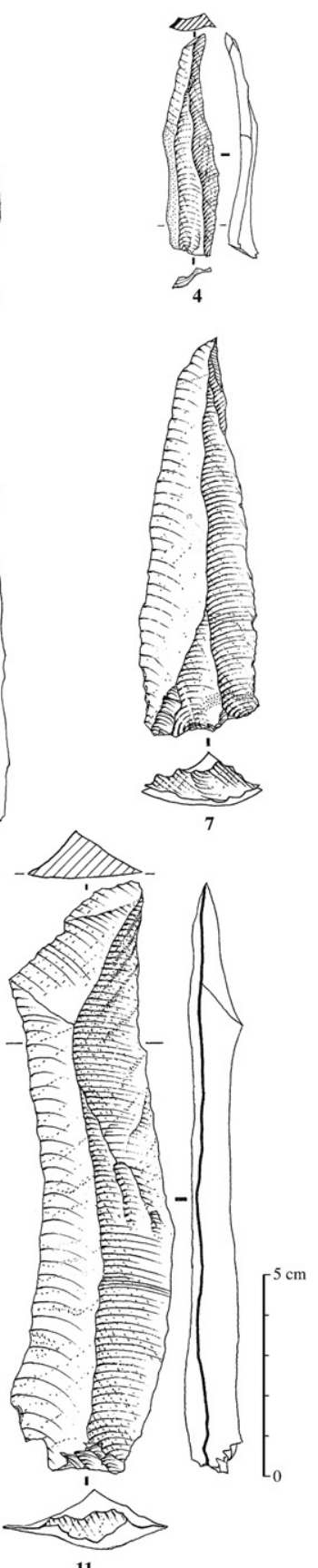

11

Figure 10. SD1 blades (1-4: cortical blades, 5-11: large thick blades); drawings by J.J.

short and do not seem to have involved successive phases of platform preparation. Based on what we can deduce from the final scar negatives, each core can be estimated to have produced between two and eight flakes. The ensuing pointed flakes were not strictly superimposed but were offset to one another.

The corresponding products (Fig. 9E, F) overlap in part with those connected to semi-tournant laminar reduction, as well as those produced by centripetal recurrent Levallois debitage. These include pointed flakes, with one or two abrupt lateral edges bearing the negatives of previous laminar removals (Fig. 12: 14-18), the initial small non-Levallois points with triangular cross sections and maximum lengths between 2 and $3 \mathrm{~cm}$ (Fig. 13: 1-3), as well as triangular flakes (Fig. 12: 1-13) and pseudo-Levallois points whose morphological axis is offset (déjeté) in relation to the debitage axis (Fig. 13: 4-6).

The production of pointed flakes cannot be qualified as Levallois debitage, as not only do the cores demonstrate minimal preparation, but the surfaces from which the pointed flakes were detached were also significantly convex. Furthermore, there are no genuine Levallois points such as those documented in the Levantine Mousterian (e.g., Meignen, 1995; Shea, 2003). Although Levallois debitage is present in the assemblage, it plays a secondary role.

Levallois production It is illustrated by a small number of cores debited on their widest surface with fracture planes being subparallel to this surface (Fig. 14: 9-11). They illustrate a variety of recurrent methods: uni- or bidirectional parallel $(n=3)$, 

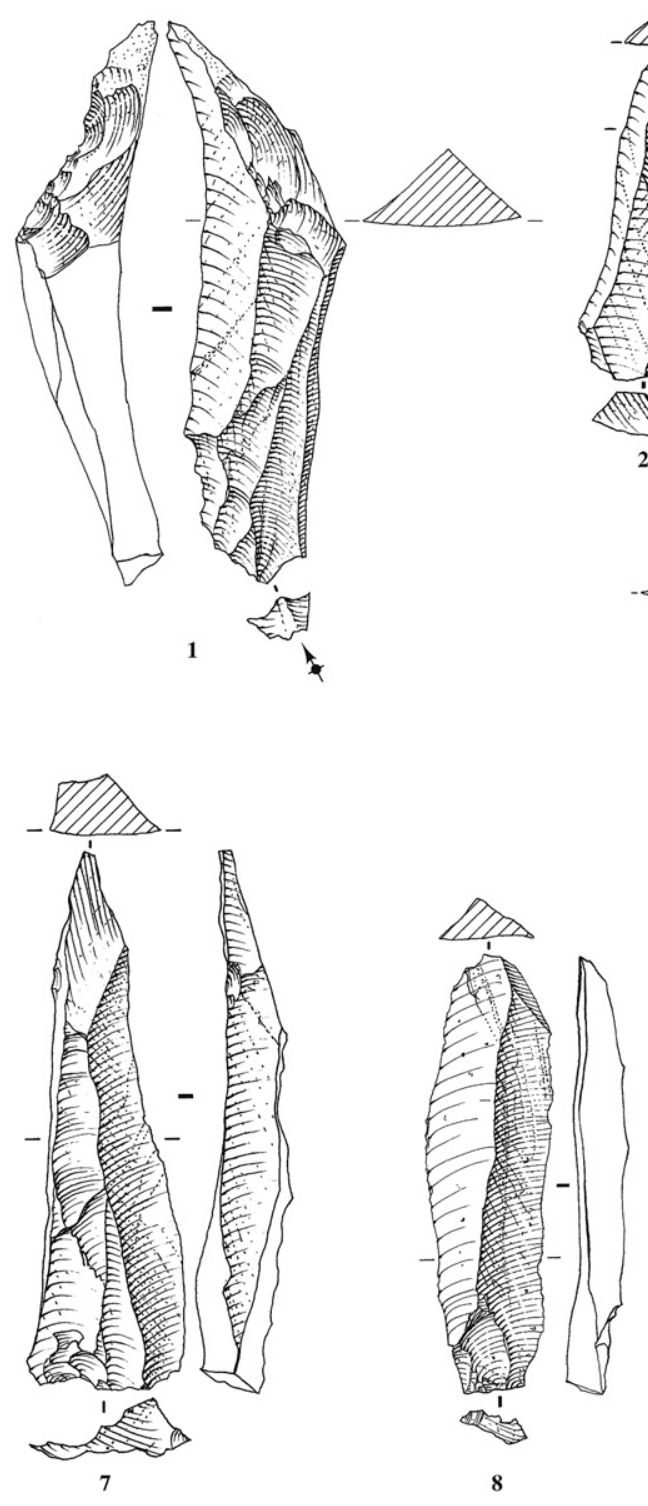
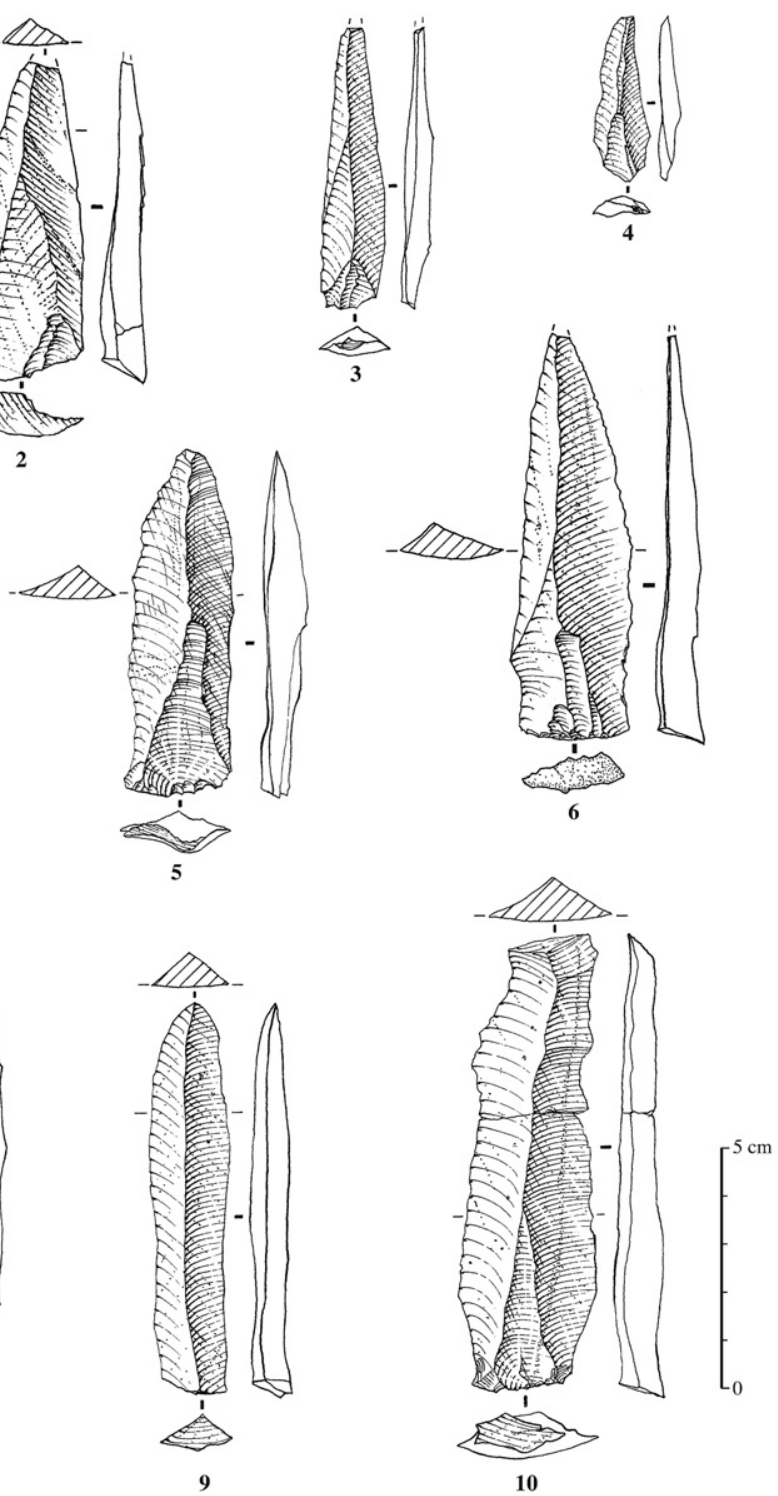

Figure 11. SD1 blades (1: partially crested blade, 2-6: small pointed blades, 7: blade with a débordant side, 8-10: thin and rectilinear blades); drawings by J.J.

unidirectional convergent $(n=2)$, and centripetal $(n=2)$. All of these cores have short sequences without preparation of the debitage surface and a minimal preparation of striking platforms by several large removals. The resulting products (Fig. 9A, B, F, G) are referred to as 'Levallois-like' products insomuch as they do not fulfill all the criteria commonly used to define the Levallois concept (Boëda, 1982, 1995), particularly in terms of the preparation and management of the core volume. These 'Levallois-like' flakes include elongated quadrangular flakes (Fig. 13: 7-10), triangular flakes (Fig. 12: 1-13), centripetal recurrent flakes (Fig. 13: 13-15), débordant flakes (Fig. 13: 11, 12), and pseudo-Levallois points (Fig. 13: 4-6).

Retouched pieces They are extremely rare and, apart from one example, are made exclusively in rhyolite $(n=25$ or $0.5 \%$ of the material $>2 \mathrm{~cm}$, Table 1 ). Several groups can be distinguished: tools with continuous retouches (partial scrapers or denticulated 'scrapers': Fig. 15: 6), and tools with notched (Fig. 15: 1, 2, 7) or denticulated edges (Fig. 15: 3, 5) to which can be added an isolated example of an atypical endscraper (Fig. 15: 4). Tools with continuous retouches $(n=10)$ rarely show more than one episode of retouch, which is clearly denticulated and invasive, perhaps designed to thin the support, or abrupt to semi-abrupt. Retouch is often limited to particular portions of the edges. Several particularly thick examples (blades and undifferentiated flakes) bear secondary modifications in the form of irregular retouch. Tools with notched edges $(n=8)$ show one or several, often inverse, notches concentrated toward the mesial section of the blank. The denticulates $(n=6)$ bear heavy retouch concentrated on a relatively limited length of their edges $(<40 \mathrm{~mm})$ and are all broken, perhaps as result of a violent impact. Blank choice is variable and shares equally between either cortical or undifferentiated products $(n=12)$, blades and Levallois-like flakes $(n=13)$, resulting in a tool kit which appears expedient and un-standardized, both in terms of retouch and blanks.

\section{Technological and functional interpretation of SD1 lithic assemblage}

Technological system At SD1, the debitage is essentially geared toward the production of unretouched pieces with long, often convergent, cutting edges. Two main core reduction strategies, one producing blades and the other producing pointed flakes, are 

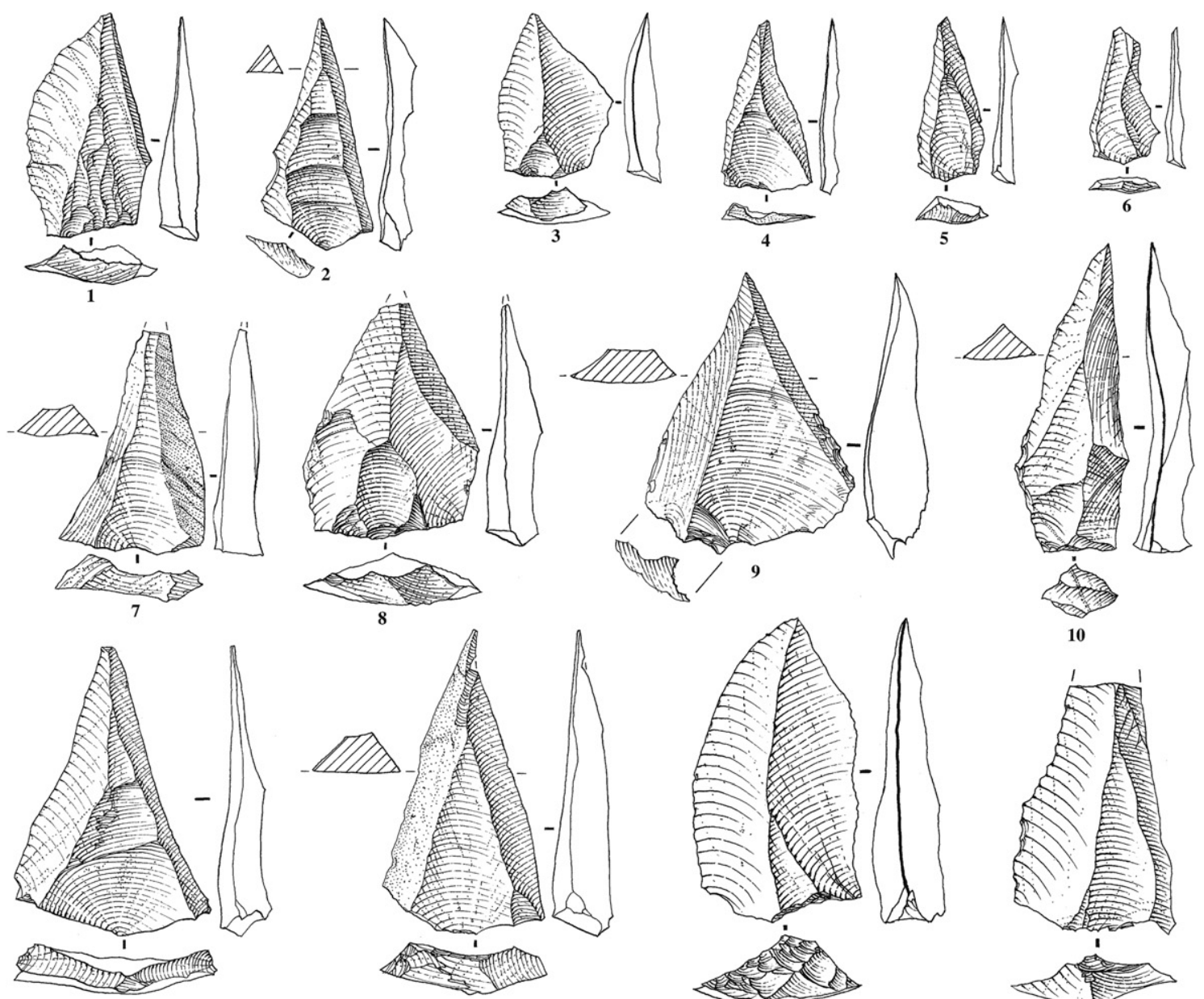

11
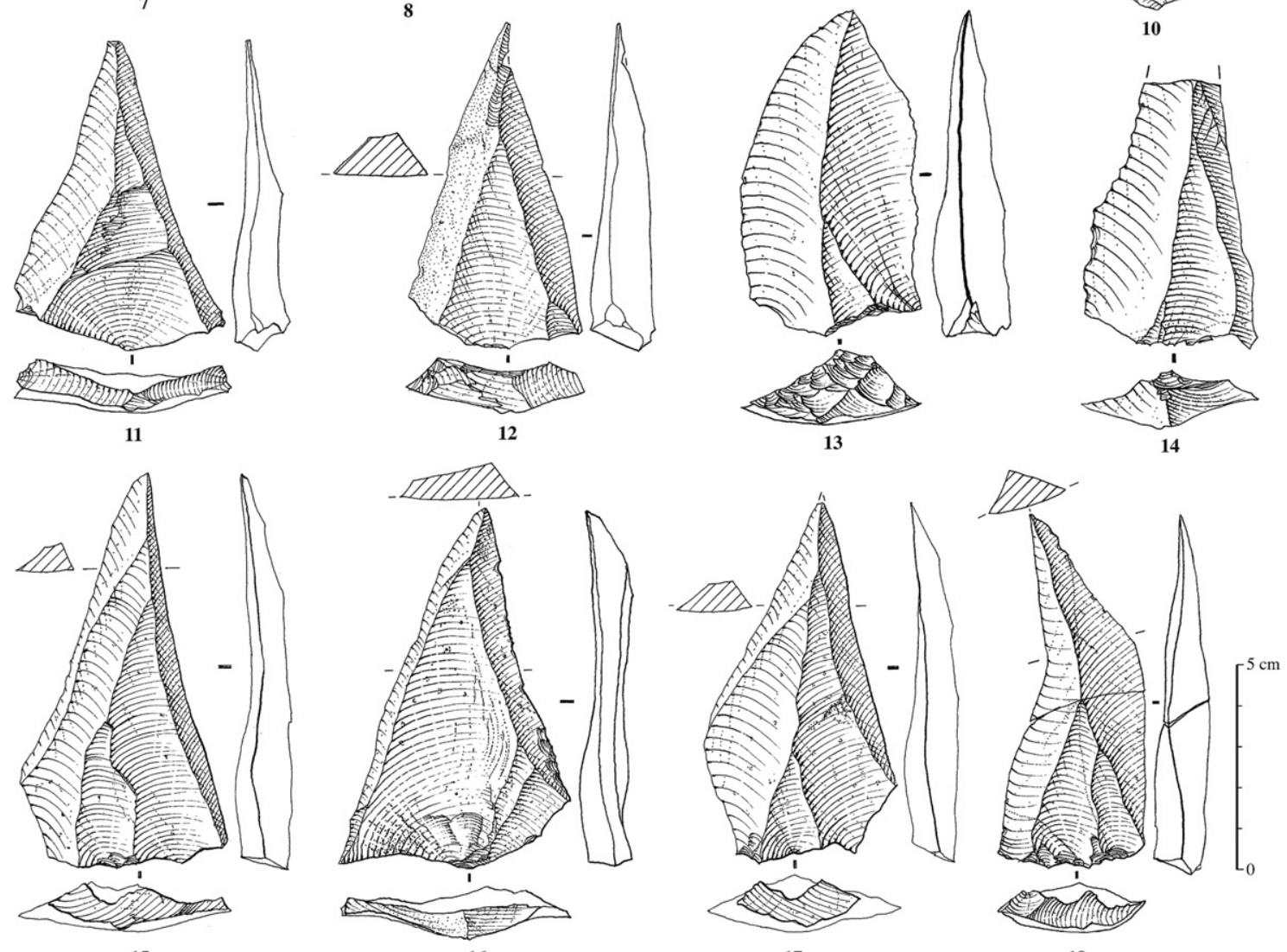

17

18

Figure 12. SD1 pointed flakes (1-13: pointed flakes, 14-18: pointed flakes with one or two abrupt lateral edges); drawings by J.J.

accompanied by a more marginal Levallois flake production. All core reduction strategies are typically Middle Paleolithic in character. Blade production is perfectly consistent with the Middle Paleolithic laminar systems documented in the Levant (Meignen, 2000; Monigal, 2001), in Central Asia (Ranov, 1995), and in Western Europe (Révillion and Tuffreau, 1994; Delagnes, 2000; Delagnes and Meignen, 2006). Blade and pointed flake productions are partly embedded within the same reduction sequences. The Levallois production represents short, simple reduction sequences with minimal initial core preparation. Whilst fulfilling the volumetric criteria defining the Levallois method (Boëda, 1982, 1995), the cores differ from Levallois cores sensu stricto as defined from Western European Mousterian assemblages (Boëda, 1988).

Simple core reduction strategies, involving minimal preparation and no management of the core's volume, are counterbalanced by a high degree of technical skill, illustrated by precise gestures, measured blows, and selective raw material procurement strategies. The angular volumes of the cobbles, pebbles and flakes allowed reduction to begin directly without any significant core 


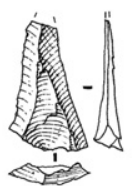

1

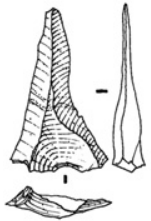

2

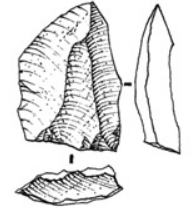

3
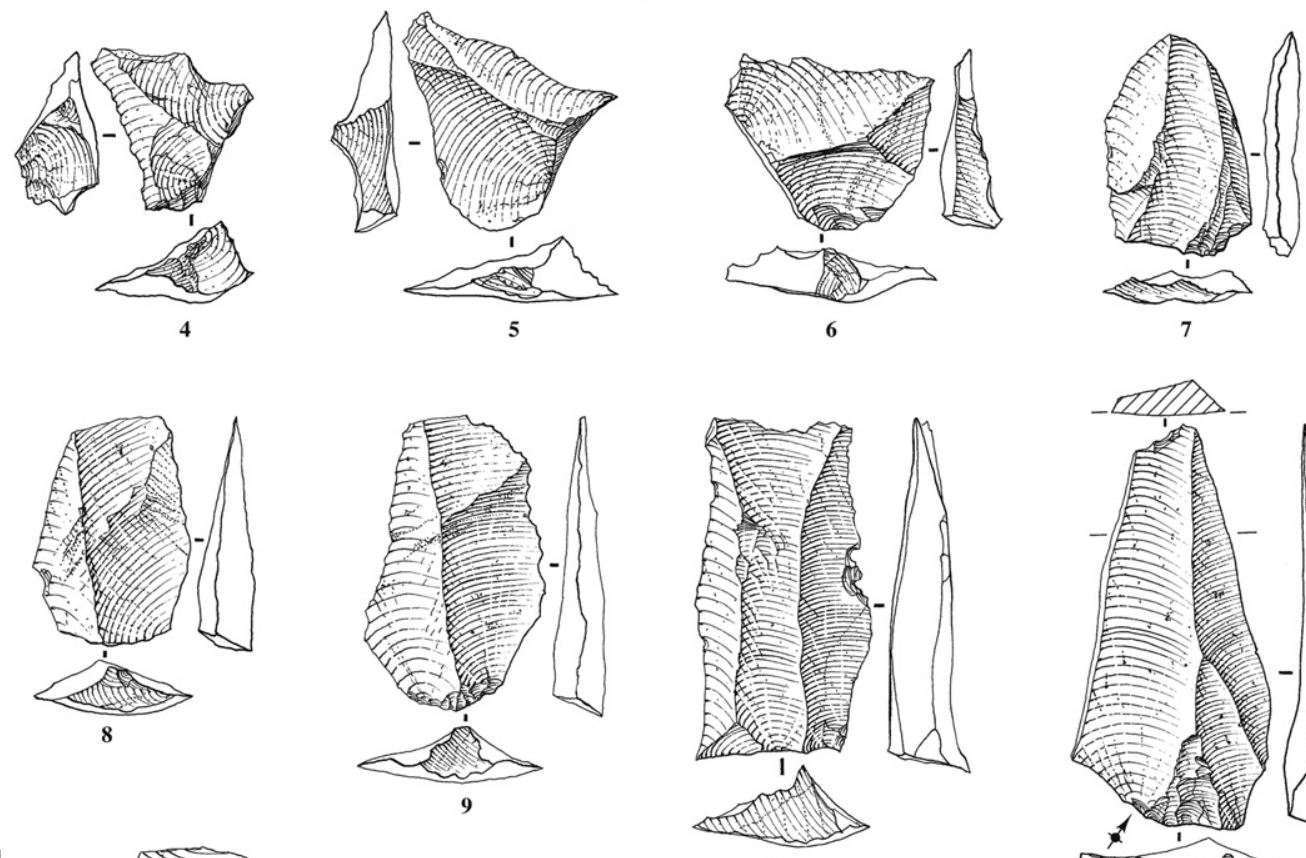

10

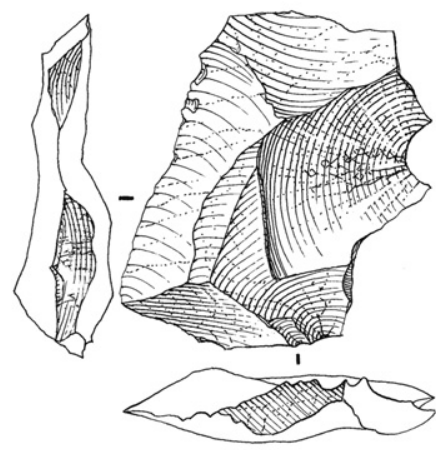

12

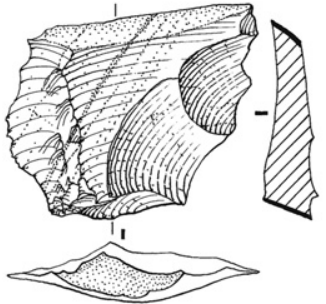

13

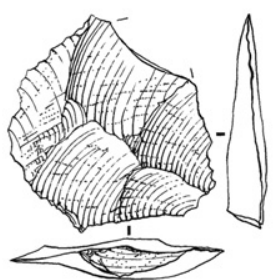

14

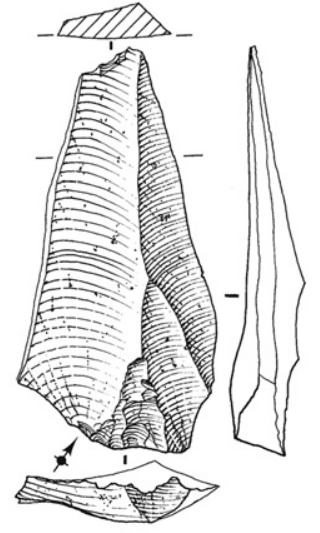

11

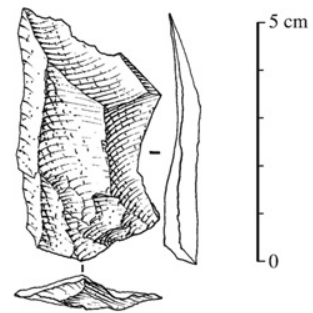

15

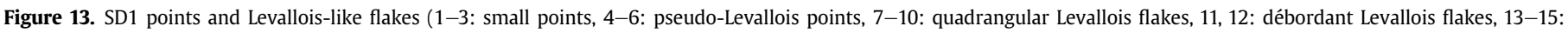
centripetal recurrent Levallois flakes); drawings by J.J.

preparation, a fact that is illustrated by opening blades (lames d'entame), which took advantage of preexisting natural crests. The minimal investment in the preparation of the cores seems to be compensated for by the application of the core reduction strategy most suitably adapted to the morphology of each block, in order to facilitate the beginning of the debitage.

Another fundamental characteristic of the debitage from SD1 is the flexibility demonstrated by the fact that distinct categories of end products are often alternately produced during the same reduction sequence. This is especially evident in the case of blades, pointed blades and flakes extracted from 'semi-tournant' cores. However, these different types of products do not represent successive reduction phases, but appear to alternate, without any predefined order, according to how debitage unfolds and the opportunities afforded by previous removals. The main refitted blocks illustrate the variety of products that can be extracted from the same core (Table 1 : blocks $1,2,4$ ). As a result of this flexibility, blades, pointed blades and flakes, and Levallois-like flakes cannot be assigned to distinct dimensional groups (Fig. 16).

Site's function It cannot be specified in detail given that the excavated area constitutes only a portion of the site's overall extension. However, the composition of the lithic assemblage clearly shows that a large part of the production was abandoned on-site. The high proportions of unretouched blades and flakes supports the hypothesis that these items were used on-site. Furthermore, the scarce retouched pieces form an expedient tool kit that complements an unretouched component demonstrating more technical investment. The lack of retouch flakes or fragments of more standardized tools effectively precludes the possibility that more formal tools were manufactured on-site and then exported. Finally, the absence of formal tools is certainly not the result of a bias in the recovered sample, but can most likely be connected to the physical properties of rhyolite, which rendered the transformation of blank edges difficult and/or unnecessary. 


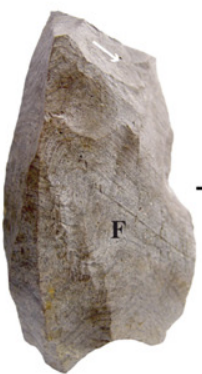

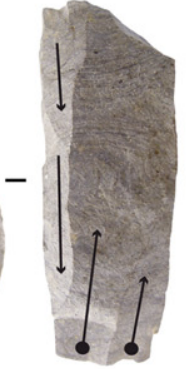

1
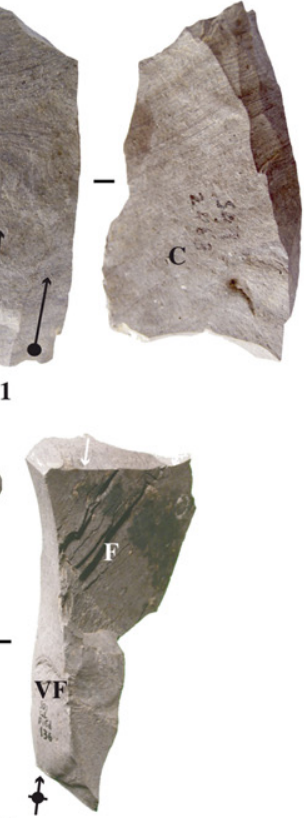
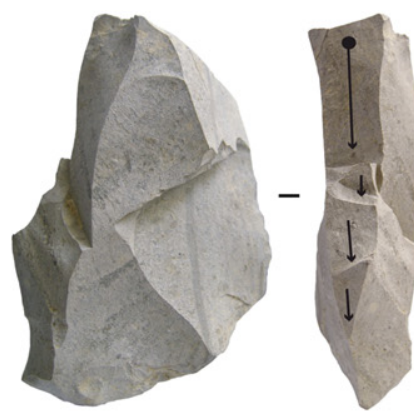

2
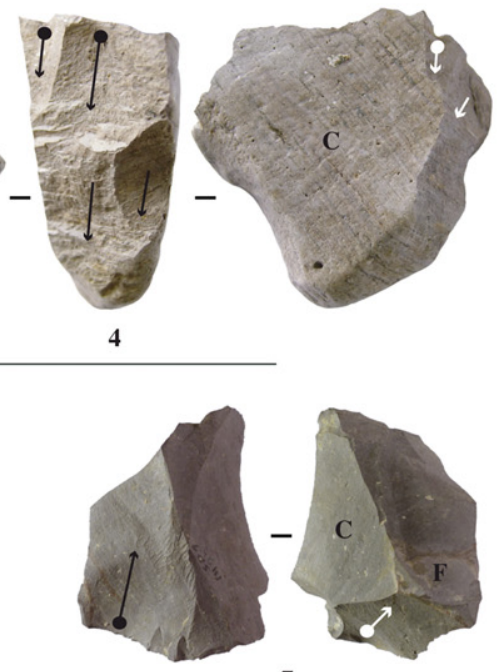

7

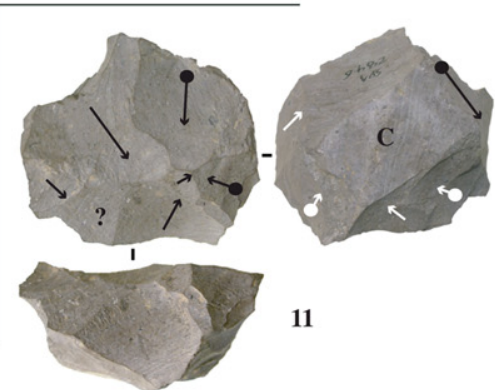

C: cortex

F: fracture

VF: ventral face

black arrow: flake or blade remova white arrow: platform preparation
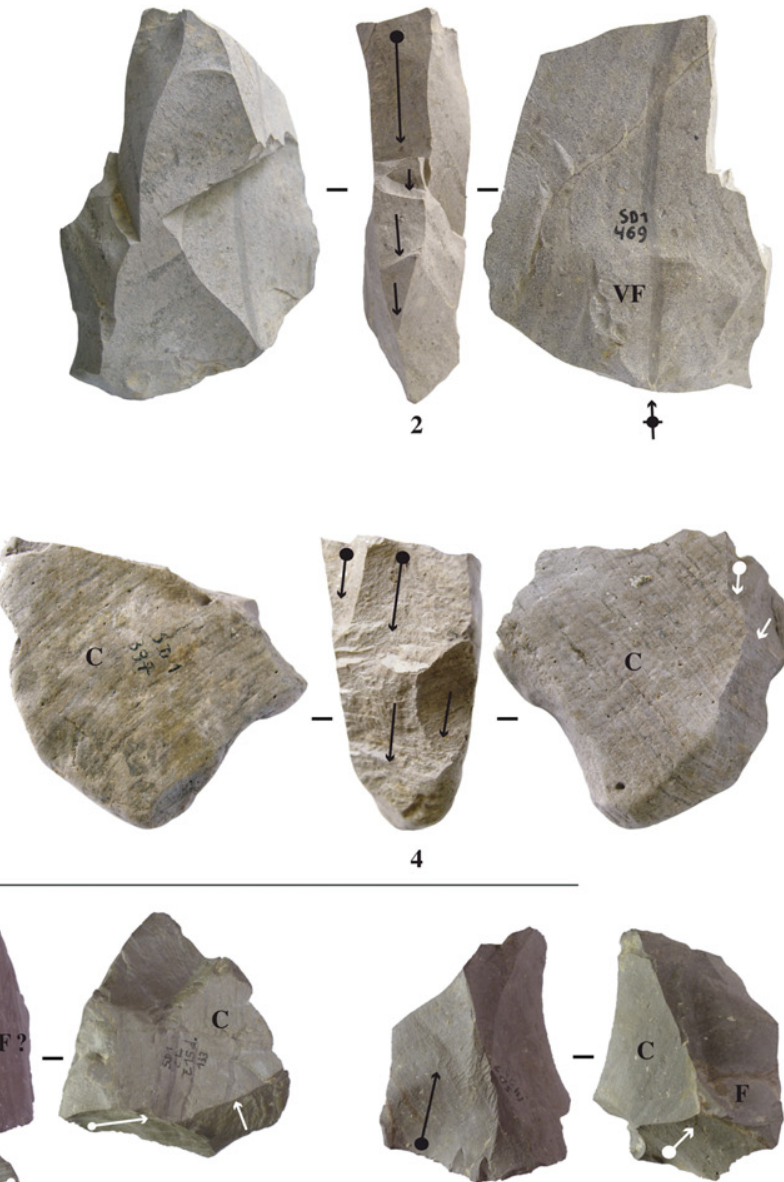

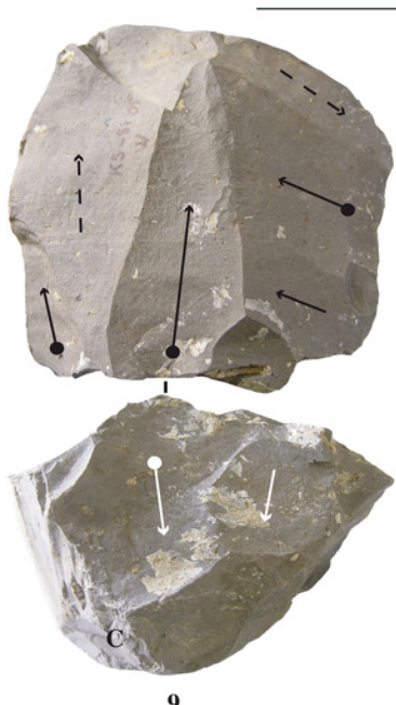

9

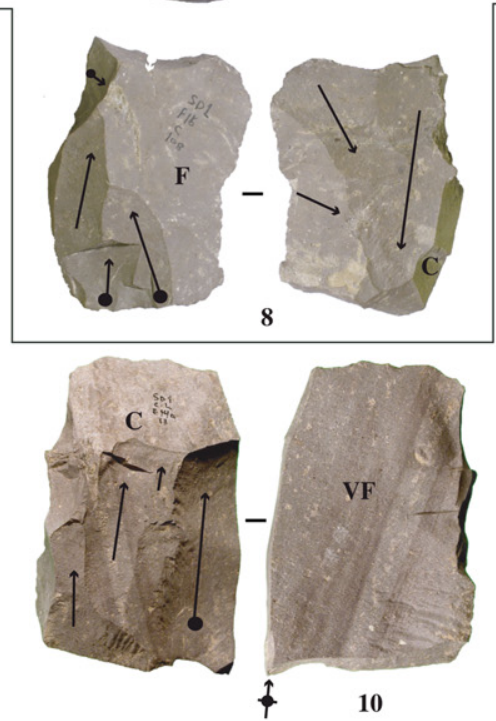



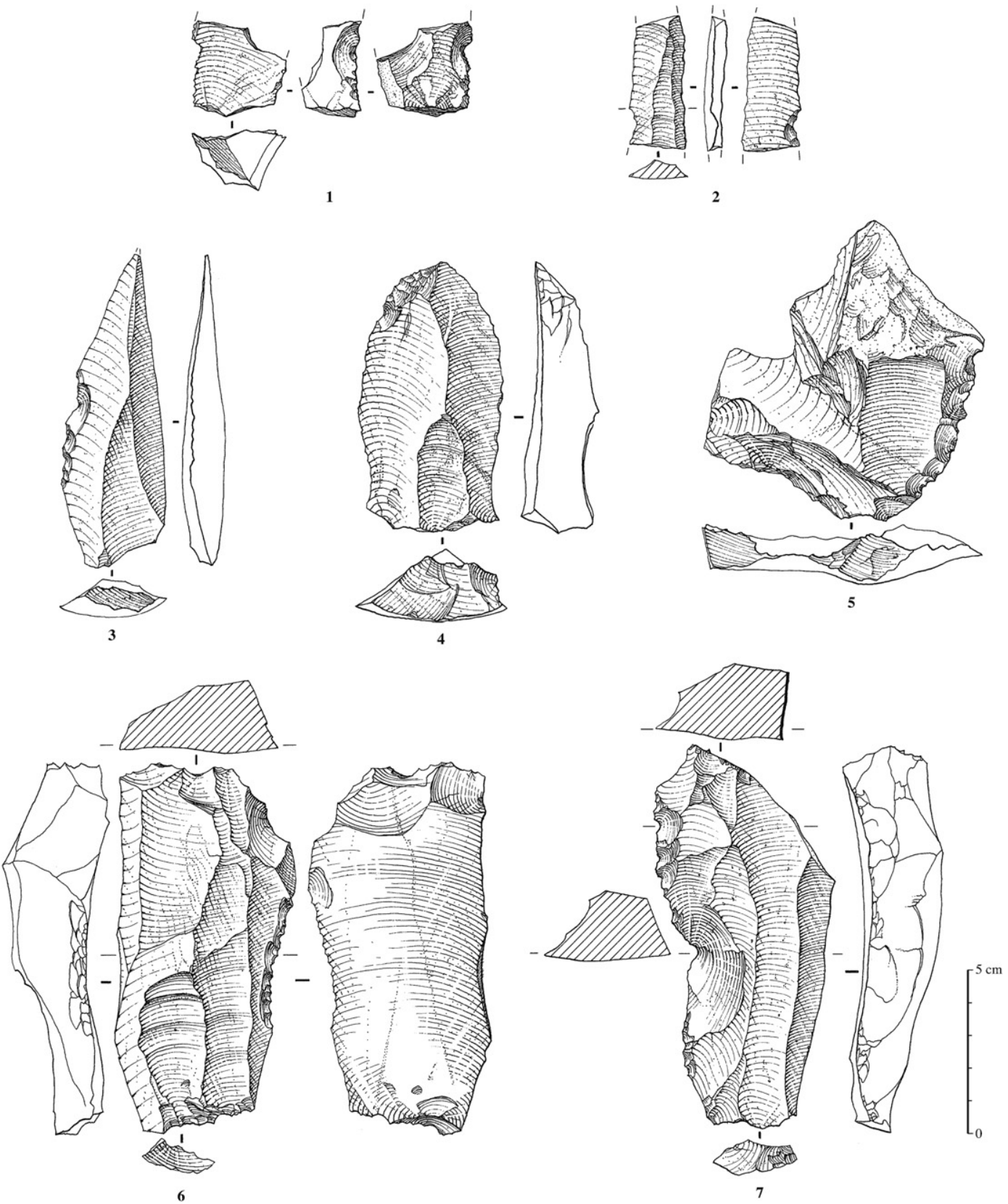

Figure 15. SD1 retouched tools (1, 2, 7: notched tools, 3, 5: denticulated tools, 4: atypical endscraper, 6: denticulated scraper); drawings by J.J.

stones, simple debitage in phonolite, basalt and quartz, and heavy duty tools made in basalt. This pattern connects various technical activities with multiple local raw material sources (i.e. alluvial plain and stormflow deposits) and confirms that diverse activities took place at SD1 within the context of a habitation site.

\section{Comparison between SD1 and SD2}

The site of SD2 is comprised of a lithic sample collected from a single level. Although no extensive excavations have yet taken place, this significant sample $(n=1336)$ can be considered representative, both quantitatively and qualitatively, for comparisons with SD1. The lithic assemblage is typified by the presence of a unifacial centripetal non-Levallois debitage (Fig. 17: 11, 12) on rounded green basalt pebbles ( 177 flakes or $13 \%$ of all products and four cores). These small pebbles $(<20 \mathrm{~cm})$ have a fairly granular texture and were debited by hard-hammer percussion with unprepared and often cortical butts. Debitage products are thick and quadrangular, non-laminar and un-standardized (Fig. 17: 7-10), with fractures frequently produced during reduction.

The rare centripetal or unidirectional recurrent Levallois flakes ( $n=38$ or $2.8 \%$, of which 13 are pointed; Fig. $17: 1-4$ ) involved highquality blocks of rhyolite similar to the majority of those exploited in the SD1 assemblage. Quadrangular Levallois flakes indicate a centripetal reduction strategy, whereas the presence of Levallois pointed flakes is more representative of a unipolar convergent strategy. The laminar flakes and blades ( $n=43$, 3.2\%; Fig. 17: 5 and 6) are comparable with those recovered from SD1 and may derive from similar debitage strategies. As a whole, the assemblages from SD1 and SD2 are clearly different in quantitative terms (Fig. 18). Pointed flakes, blades and Levallois-like products are considerably less abundant in SD2 and the differences between both sites are 


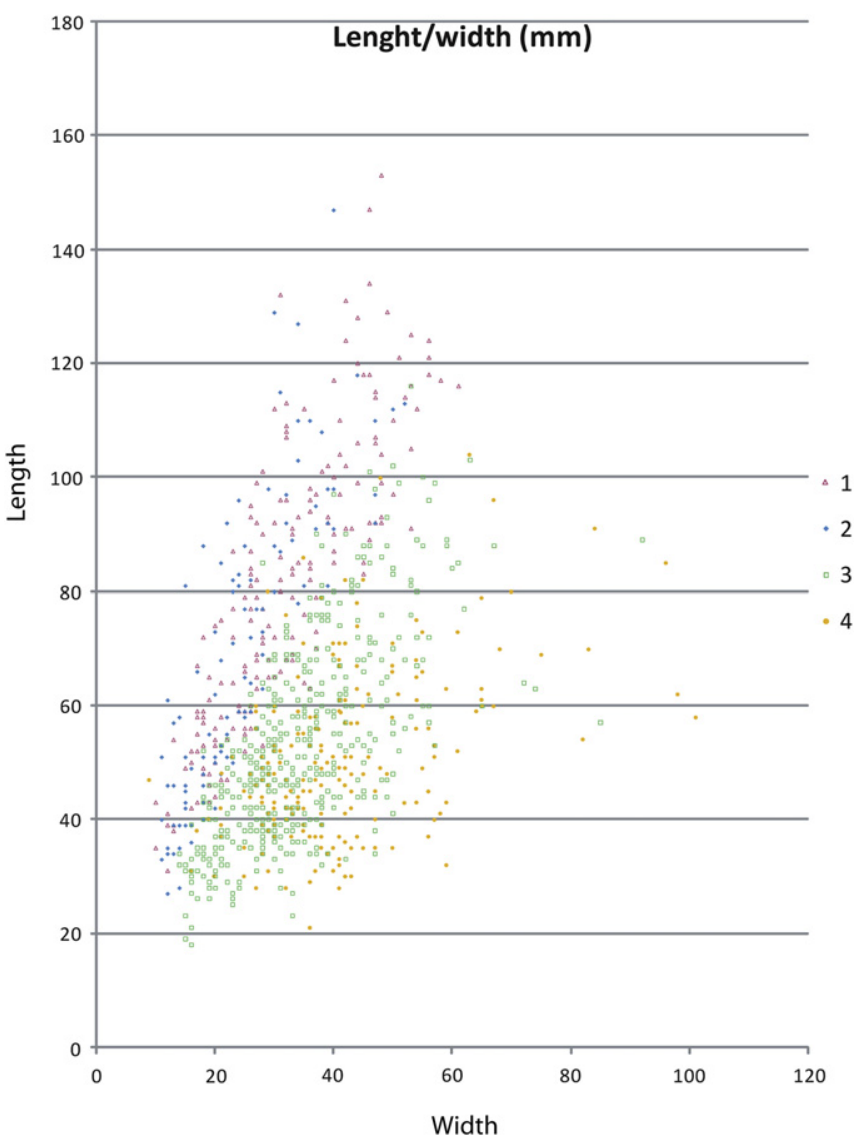

Figure 16. Length/width distribution of the four main categories of end products at SD1 (1: blades, 2: pointed blades, 3: pointed flakes, 4: Levallois flakes).

highly significant (Pearson: $n=45.655,149.042$ and 141.483; $p<0.001$, for the three technological categories mentioned above). Furthermore, neither Levallois cores nor blade cores nor related waste-products were identified at SD2, raising questions as to whether or not these end products were produced on-site. Nevertheless, the rare blades and Levallois-like flakes from SD2 do not differ significantly from those of SD1. The expedient centripetal reduction strategy involving unprepared cores that prevails at SD2 is not documented at SD1.

\section{Discussion}

\section{An inland occupation during MIS 3 arid conditions}

The Bab-al-Mandab Strait and the Arabian coastlines have been proposed as the most plausible expansion routes of the early modern human groups who spread out of Africa and toward Asia ca. 60-50 ka (Lahr and Foley, 1998; Macaulay et al., 2005; Rose, 2004a), although the lack of evidence on both sides of the southern Red Sea makes confirming this scenario extremely difficult. These migrating groups would have rapidly dispersed out of Africa and into Arabia (Lahr and Foley, 1994, 1998; Stringer, 2000) along the rim of the Indian Ocean and/or along the Red Sea shore, taking advantage of their abilities to effectively exploit aquatic resources (Klein, 1999; Stringer, 2000; Walter et al., 2000; Parkington, 2001; Mellars, 2006b; Beyin and Shea, 2007; O'Connor et al., 2011) and deploy complex projectile technology (Shea and Sisk, 2010). The scenario of a rapid and biologically driven shift from 'archaic' to modern behaviors in Eurasia is severely questioned by the complex, non-linear, asynchronous and polycentric development of these so-called modern behaviors (d'Errico, 2003; Dennell and Roebroeks, 2005; Hovers, 2009b; Conard, 2010; Zilhão et al., 2010). Furthermore, the model of a coastal dispersal of modern humans out of Africa ca. 60-50 ka, although plausible, is largely untestable given that most of the Red Sea shorelines from this time period are now submerged (Bailey et al., 2007; Bailey, 2009). Conversely, the majority of Middle Paleolithic sites known from the Arabian Peninsula are located significantly inland of current littorals (e.g., Parr et al., 1978; McClure, 1976, 1978; Zarins et al., 1980, 1981; Petraglia et al., 2011). The Middle Paleolithic groups who occupied the Arabian Peninsula were likely adapted to a wide range of habitats, including the most continental ones.

The geographic setting of the Wadi Surdud is consistent with a significant expansion of Middle Paleolithic humans into inland territories under arid climatic conditions. These sites are located in a continental basin, which, according to bathymetric data from the Red Sea (Siddall et al., 2003), was situated some $120 \mathrm{~km}$ from the coast at the time of their occupation. The Holocene dune formations that blanket the Tihama coastal plain immediately to the west of the Wadi Surdud complex conceal all potential traces of human occupation prior to this period. Although these coastal lowlands might also have offered resources for the Pleistocene populations (Bailey, 2009), the significantly more arid climate of the Tihama coastal plain presented conditions less favorable to long-term settlement than those of the interior foothills where the sites are located. Current mean annual rainfall is between 300 and $400 \mathrm{~mm}$ and drops to less than $100 \mathrm{~mm}$ along the coast (Farquharson et al., 1996). Prevailing arid conditions during the occupation of SD1 are signaled by the presence of fauna (particularly Equus sp. cf. E. hemionus) adapted to steppe environments as well as by several different environmental proxies (e.g., precipitations of calcrete and gypsum in the sediment indicative of high evaporation rates). Enduring biotic resources were also present, as attested to by the cyclical swelling of the Wadi Surdud, which represented a standing source of water, and by the presence of herbivores within the local environment of the site. Abundant mineral resources were also locally available and provided a range of suitable materials from which the occupants of the basin could easily make stone tools.

The adaptation of the occupants of Wadi Sudud to an arid environment significantly nuances the environmental determinism inherent in nearly all models concerning the peopling of southern Arabia. These models posit that extreme climatic fluctuations within the Saharo-Arabian arid belt throughout the course of the Upper Pleistocene would have played a decisive role in human demography with expansions being favored during humid phases (pluvial events) and impossible during hyper-arid phases (Lahr and Foley, 1994, 1998; Cohen et al., 2007; Scholz et al., 2007; Rose, 2007b; Parker and Rose, 2008; Parker, 2009). These climatic extremes are well documented in a series of dated speleothems from caves in Yemen and Oman (Burns et al., 2001; Fleitmann and Matter, 2009; Fleitmann et al., 2011), as well as from dune accumulations, desiccated paleolakes, or ancient riverbeds (Preusser et al., 2002; Stokes and Bray, 2005; Parker and Rose, 2008; Preusser, 2009; Rosenberg et al., 2011, 2012). However, while intermediate climatic conditions prevailed throughout much of the Upper Pleistocene, they are rarely considered in the models advanced, most likely due to their low visibility in the available environmental proxies. The occupation of the Wadi Surdud demonstrates that non-ephemeral human settlements were indeed present in southern Arabia during these intermediate, semi-arid to arid, climatic conditions.

The bioenvironmental setting of the Wadi Surdud basin certainly accounts for the attractiveness of the region, even during arid periods. In the context of the Saharo-Arabian arid 

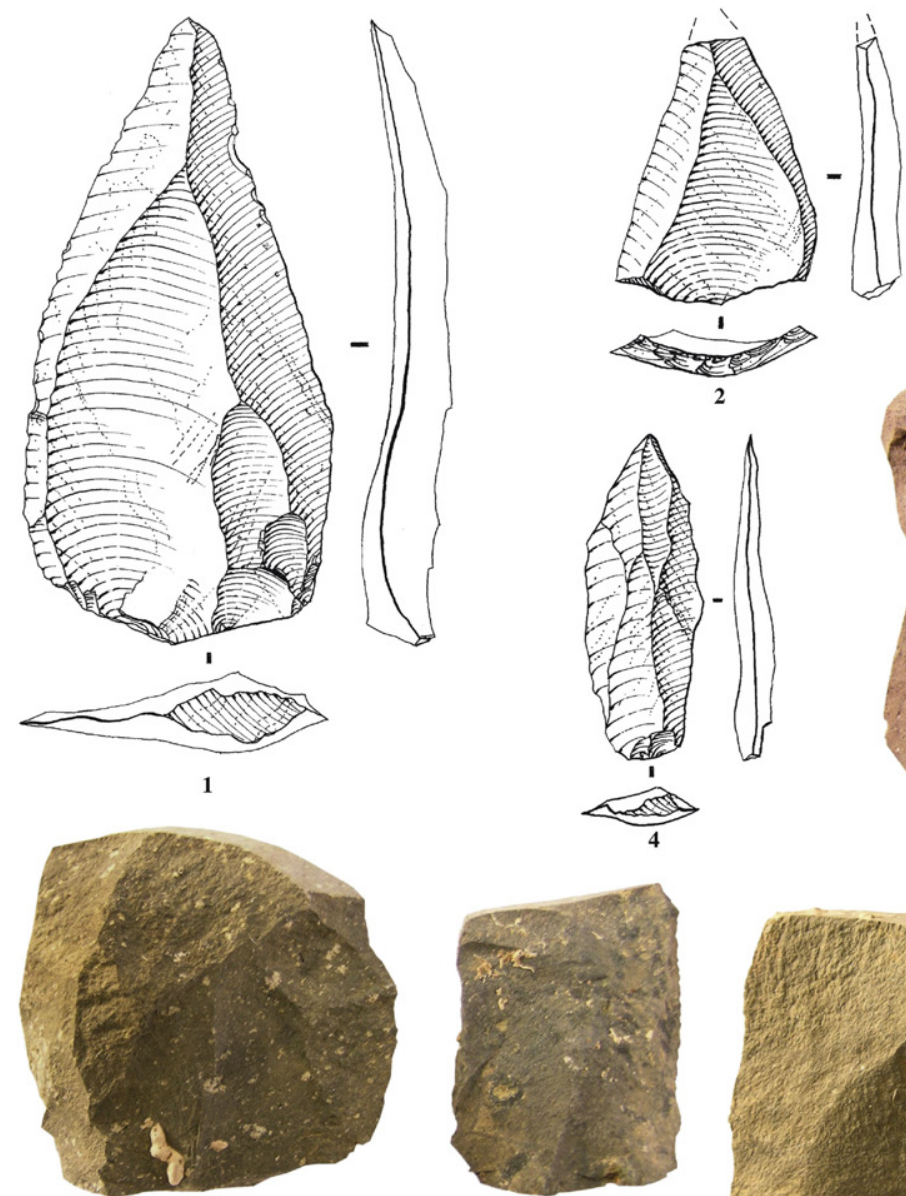

7

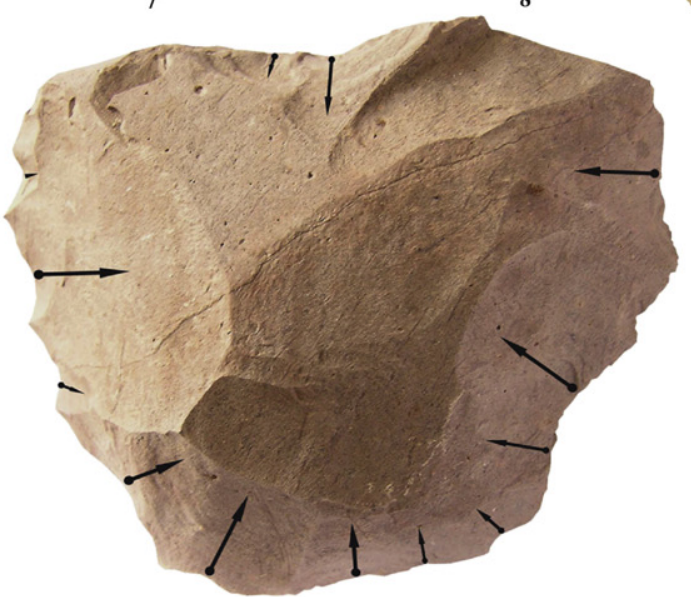

11
2
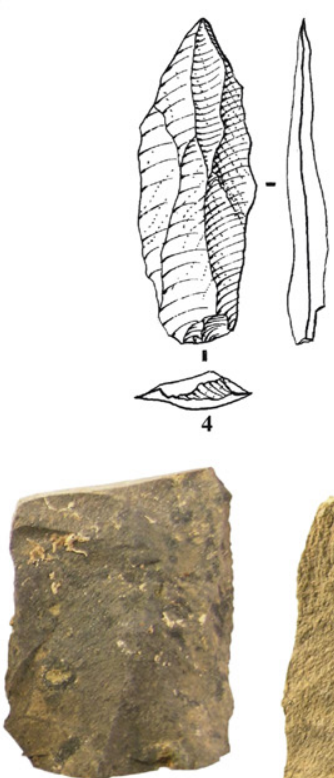

8

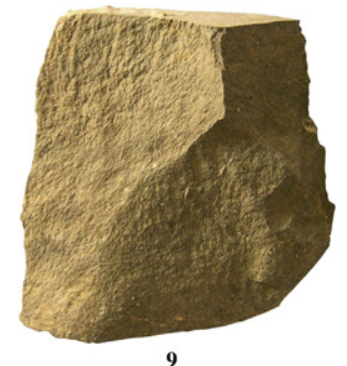

9

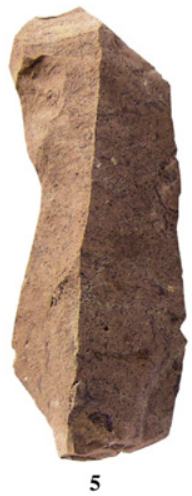

5

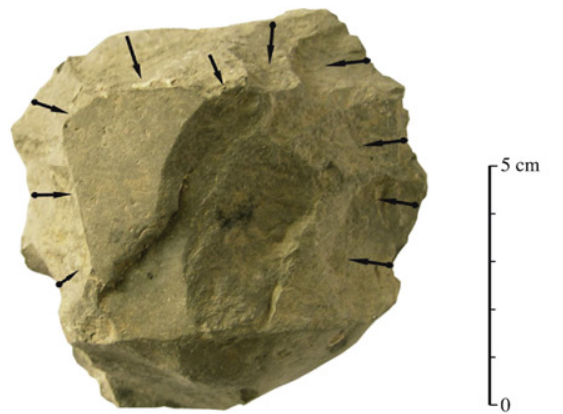

12
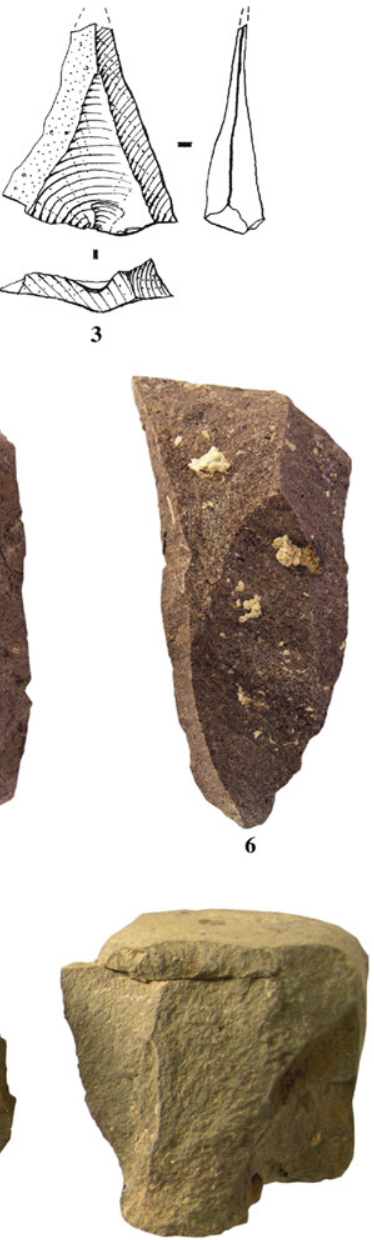

10

Figure 17. SD2 lithic products (1-4: pointed flakes, 5 and 6: blades, 7-10: quadrangular flakes, 11 and 12: unifacial centripetal cores); drawings by J.J.

belt, the medium altitude foothills form ecological niches with long-lasting and predictable sources of water and herbivores that provided ideal conditions for human settlement (see Bailey and King, 2011). In the Arabian Peninsula, this type of ecological niche is found in two main regions that border the southern part of the Rub al-Khali desert: the foothills of the western highlands along the Tihama coastal plain to the west, and the foothills of the Hajar Mountains to the east. These regions provided sustainable biotic resources and may have served as refugia where core populations retreated when climatic conditions deteriorated (Rose and Petraglia, 2009; Rose, 2010; Dennell et al.,
2011). All of the Middle Paleolithic occupations documented in the Arabian Peninsula during the MIS 3 are located in these two regions, including at least three successive phases of human occupations in the Wadi Surdud basin, and one (assemblage A), or perhaps two (with assemblage B, not yet precisely dated), human occupations at Jebel Faya (UAE) (Marks, 2009; Armitage et al., 2011). In both contexts, the Middle Paleolithic assemblages are assigned to local traditions that likely emerged and developed regionally. This phenomenon of 'regionalism' is consistent with a scenario of population contraction within core regions during phases of aridification. 


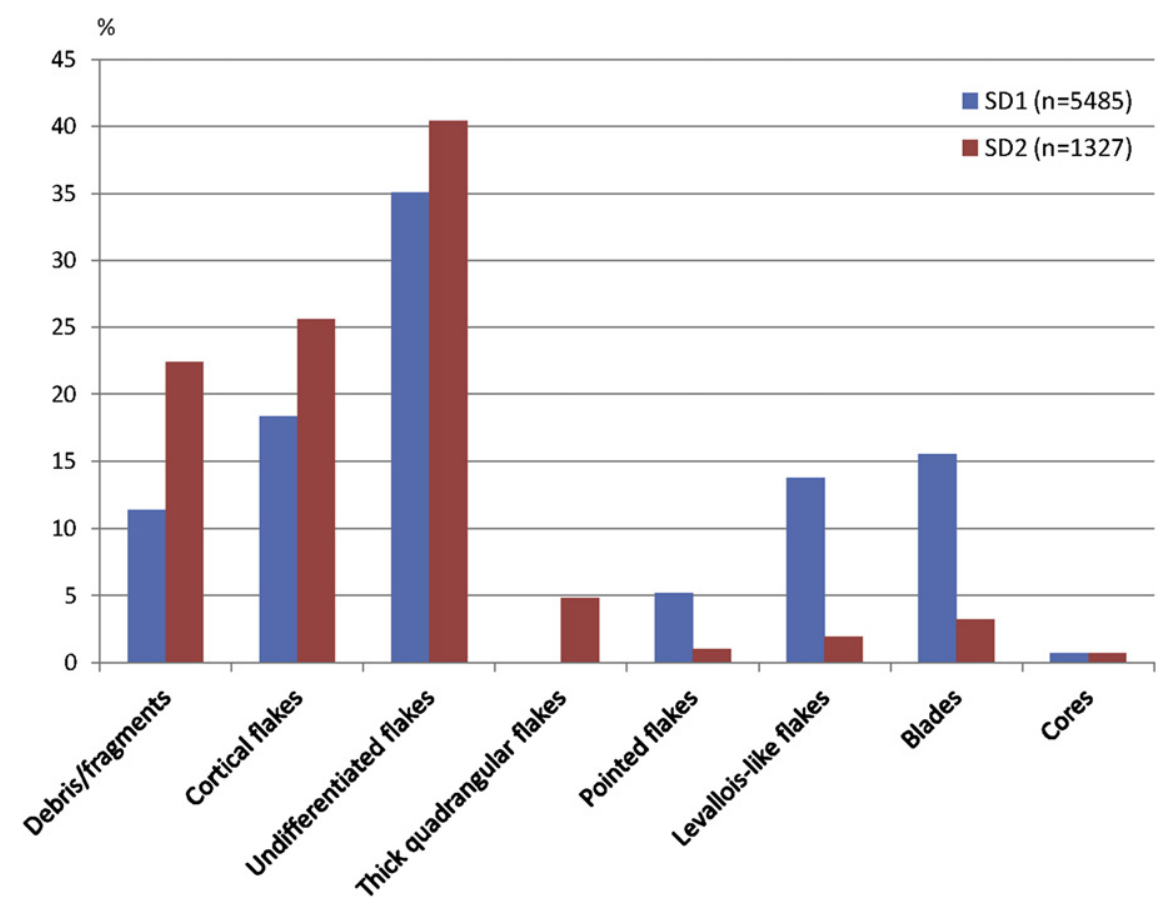

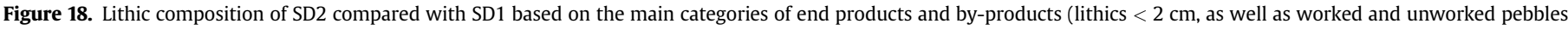
are not included in the graph).

\section{Toward a vision of a more diversified Arabian Middle Paleolithic}

The assemblages from SD1 and SD2 can be assigned to the Middle Paleolithic and portray original technological features that highlight the diversity of this techno-complex in the Arabian Peninsula. The Middle Paleolithic is still poorly documented in this region, where it has essentially been defined by the presence of Levallois debitage from surface sites identified during surveys. Occurrences of Levallois debitage in the Arabian Peninsula were documented relatively early on by Caton-Thompson $(1938,1953)$, followed by Van Beek et al. (1963), Inizan and Ortlieb (1987) and Amirkhanov (1991, 1994). More recent archaeological surveys have established the presence of Levallois debitage in the Jubbah basin of Saudi Arabia (Petraglia and Alsharekh, 2003; Petraglia et al., 2011), in the UAE region of Fili, near Sharjah (Scott-Jackson et al., 2008; Wahida et al., 2008), the center of Oman, as represented by the Sibakhan facies with its unipolar convergent Levallois cores (Rose, 2006), as well as in Yemen, at the Wadi Wa'shah, the Wadi Sana, and in the western region of Hadramawt (Crassard, 2008, 2009; Crassard and Thiébaut, 2011).

Stratified Pleistocene sites have recently exposed a more diversified vision of the Arabian Middle Paleolithic, which can be seen in the coexistence of various core reduction strategies (laminar, discoidal, or even centripetal) alongside the Levallois method, not only at Wadi Surdud, but also at a number of recently excavated sites (Marks, 2009; Armitage et al., 2011; Petraglia et al., 2011). Furthermore, the Levallois method has recently been shown to vary regionally (Crassard, 2008, 2009; Crassard and Thiébaut, 2011; Rose et al., 2011). This regional diversity of the Arabian Middle Paleolithic (Rose, 2007a; Crassard, 2008, 2009; Petraglia et al., 2010; Crassard and Thiébaut, 2011) argues in favor of diverse origins and exterior influences acting alongside more locally rooted technological developments (Marks, 2008), even if the contextual record is still too sparse to fully appreciate the chronology of these different lithic techno-complexes. Given this diversity, a uniquely East African origin for the Middle Paleolithic Arabian populations can no longer be advanced.
What stone tools can (and cannot) tell us about settlement dynamics across Arabia?

The only available data concerning the material culture of the human groups who settled in Arabia ca. 60-50 ka ago consists of stone tools, as there is no evidence of symbolic activity, nor a robust faunal record from which subsistence strategies can be reconstructed. The most commonly advanced element of comparison between lithic assemblages relates to the various characteristic stylistic tool forms shared by sites belonging to the same regional and chronological context. For example, the unifacial and bifacial points of the East African Middle Stone Age (MSA) (Clark, 1988) or the tanged Aterian points from North Africa (Reygasse, 1922; Tixier, 1958-1959), represent tools whose stylistic characteristics are so pronounced that they are considered to be pertinent cultural markers. While the industries from SD1 do not contain formal tools of any particular stylistic significance, only the core reduction strategies may be used for comparison. These strategies reveal a suite of technical knowledge that is even more informative than what can be extracted from tools alone, as they imply a higher degree of social learning.

At a local scale, the SD2 assemblage reveals more expedient technological features when compared with SD1. This is highlighted by the predominance of simple centripetal debitage and by the weak representation of laminar and pointed products which were likely produced off-site. The persistence of certain end products in both assemblages suggests a possible occupational continuity at the scale of the Wadi Surdud basin itself. It is thus conceivable that the population responsible for the SD1 assemblage persisted locally and developed their own local Middle Paleolithic tradition that became simpler at SD2, and/or adapted to distinct functional needs, in a region that provided favorable conditions for long-term settlement.

On the broader scale of the Arabian Peninsula, the relevant points of comparison are rare, given the extreme paucity of stratified Paleolithic sites. The site of FAY-NE 1 at Jebel Faya (UEA) has produced lithic industries that are potentially comparable, 
within a well-established chronostratigraphic framework (Marks, 2009; Armitage et al., 2011). The archaeological assemblages from this site, issuing from three successive levels, are older than SD1 (assemblage C, ca. 120-100 ka BP), younger (assemblage A, ca. $40 \mathrm{ka} B P$ ), and of uncertain intermediate age (assemblage $B$, situated between $\mathrm{C}$ and $\mathrm{A}$ ). The techno-typological aspects of assemblage $C$ suggest to the authors an affinity with the East African MSA based essentially on the presence of bifacial and foliate pieces, whereas the assemblages from levels A and B, bearing no obvious affinities with either the East African MSA or the Levantine Middle Paleolithic, would demonstrate a more local development (Armitage et al., 2011). The assemblage from level B of FAY-NE 1 presents the largest number of commonalities with SD1, especially the prominence of flake debitage combined with the production of rare blades by a variety of unipolar convergent core reduction strategies (Armitage et al., 2011; Supplementary Online Materials).

Extra-regional comparisons are limited by the poor resolution of relevant technological data, as well as by the diversity of debitage modes documented in neighboring areas. It is thus difficult to directly compare SD1 with the East African MSA or the Late Levantine Mousterian given the variability of the debitage modes proper to these two entities (see McBrearty and Brooks, 2000; Hovers, 2009a). Broadly speaking, recurrent unipolar convergent methods are the hallmark of the late Levantine Mousterian (Meignen, 1995) and echo the methods employed at SD1 for the production of flakes and blades. However, the contemporaneous Tabun B assemblages, typical of the final stages of the Levantine Mousterian (Copeland, 1975), show a higher degree of technical sophistication, particularly in terms of relatively standardized Levallois and laminar products with careful, often facetted, platform preparation. The most characteristic expression of these industries is the broad-based points with well-prepared chapeau de gendarme striking platforms, although never in high proportions in the Levantine series. They are absent at Wadi Surdud, and furthermore, Levallois debitage plays a secondary role at both SD1 and SD2, where pointed flakes and blades are predominantly produced using simple core reduction strategies, involving minimal core management. Thus, the Levallois debitage at Wadi Surdud differs significantly, both qualitatively and quantitatively, from the Levantine Levallois debitage. Some affinities between the SD1 assemblage and the Levantine Mousterian are still plausible, but would relate more to indirect temporal and geographical connections between the two regions, rather than any direct cultural affiliation.

No clear affinities appear between the SD1 assemblage and the East African MSA. Unlike the material recovered at SD1, the East African MSA shows a significant predominance of Levallois methods, often associated with a discoidal debitage for the production of large, thick flakes used as blanks for the manufacture of unifacial and bifacial points. When a significant blade production is documented in East and North-East Africa, as in the Levant, it is either associated with early Middle Stone Age/early Middle Palaeolithic assemblages (e.g., Kapthurin in Kenya: McBrearty and Brooks, 2000, and Gademotta/Kulkuletti in Ethiopia: Wendorf and Schild, 1974) or with much younger ( $<35 \mathrm{ka} \mathrm{BP})$ transitional MSA/LSA industries characterized by elaborate blade and bladelet production (e.g., sites from the Nile valley complex: Van Peer and Vermeersch, 1990).

An attempt at a site-by-site comparison with neighboring regions provides additional, although contrasting information. In technological terms, the combined production of blades, pointed blades and flakes issuing from a variety of core reduction strategies with relatively simple core volume management can be found in neighboring regions at a number of nearly contemporaneous sites. These assemblages are assigned to distinct Middle Paleolithic or Middle Stone Age techno-complexes based upon differences in formal tool kits and include the site of Midishi 2 (assemblage CSUc) in Somalia (Gresham, 1984), assigned to the 'Somaliland Stillbay' type MSA by Clark (1982) and older than 40 ka BP (Brandt and Brook, 1984); the Late Levantine Mousterian levels from Amud Cave (layer B1, Hovers, 1998) in Israel, dated to between 65 and $55 \mathrm{ka}$ BP (Valladas et al., 1999); and the Aterian levels from the Haua Fteah in Libya (levels XXX-XXXII) (McBurney, 1967; Moyer, 2003; Spinapolice, pers. comm.), estimated at around $50 \mathrm{ka}$ BP (McBurney, 1967). The recently described assemblage B from Jebel Faya (Marks, 2009; Armitage et al., 2011) also seems to present some similarities with this group of sites.

Several scenarios could explain these geographically distant and dispersed similarities: (i) they could simply reflect phenomena of technological convergence, a possibility which cannot be ruled out, given the substantial distances separating the sites, and that simple debitage more likely represents convergence than do elaborate ones; (ii) they could portray a remote common technological background shared between the Arabian Peninsula, the Levant, North and East Africa, which may have been the result of previous inter-regional connections or contacts, rooted into the early Upper Pleistocene, with subsequent independent trajectories producing distinct techno-typological facies. Whatever the scenario, our data are consistent with assumption that Upper Pleistocene populations in Arabia experienced significant phases of isolation, during arid phases of MIS 3.

Whether or not the Middle Paleolithic occupation of Wadi Surdud can be attributed to modern humans or to a human group related to the Neanderthals remains a totally open question. As no sound technological markers exist for distinguishing Neanderthals from early modern humans (Zilhão, 2001, 2010; d'Errico, 2003; Hovers, 2009a; Shea, 2010), neither of these alternatives can be ruled out. What is certain is that the people who settled in Wadi Surdud did not belong to migrating groups who left Africa around $60 \mathrm{ka}$ and introduced new modern behaviors into Arabia, as they were still firmly embedded in a Middle Paleolithic tradition. If the authors of the SD1 assemblage were modern humans, they either derived from the human groups who already occupied the Arabian Peninsula during the Lower Paleolithic (Petraglia, 2003), or descended from a population of modern humans whose members dispersed into the Arabian Peninsula between 120 and $80 \mathrm{ka}$, during the humid phases of MIS 5 (Petraglia et al., 2010; Armitage et al., 2011; Rose et al., 2011). This would be in line with the recently formulated hypotheses following the discoveries at Jebel Faya (UAE), the Nefud desert (Saudi Arabia), and the region of Dhofar (Oman) (Rose and Petraglia, 2009; Petraglia et al., 2010, 2011; Armitage et al., 2011; Rose et al., 2011).

Alternatively, based on the currently available evidence, the occupants of Wadi Surdud could also represent a southern group of Neanderthals, given that the Neanderthals are the only human group so far documented north of the Arabian Peninsula, in the Near East, Levant and Zagros regions around 60-50 ka. At the larger scale of the Arabian Peninsula, where no Pleistocene hominin remains have been recovered so far, multidirectional influxes of populations, related to distinct human groups, may have occurred throughout the Pleistocene. At present, this scenario fits a set of recent discoveries and genetic analyses of both human fossil remains and modern population samples (e.g., Gunz et al., 2009; Krause et al., 2010; Green et al., 2010; Abi-Rached et al., 2011; Hammer et al., 2011; Martinón-Torres et al., 2011; Rasmussen et al., 2011; Reich et al., 2011), which point to new, more complex scenarios of large-scale population dispersals and genetic admixture across Eurasia. 


\section{Conclusions}

New evidence from the Wadi Surdud site complex, in western Yemen, adds important elements to the debate concerning settlement dynamics in Arabia during the Upper Pleistocene. More specifically, our results reveal a previously unreported scenario where a Middle Paleolithic tradition developed locally in an inland area during an early arid phase of MIS 3, with no direct influence from either East Africa or the Levant. The Wadi Surdud basin represents a favorable eco-zone for non-ephemeral human settlements. Even during arid periods, the region provided sustainable sources of freshwater and attractive habitats. It may have functioned as a core region where populations retreated to during harsher periods. These results are consistent with the scenario of a significant human expansion into Arabia, either from Africa or from the Levant during humid phases of MIS 5, contemporaneous with MIS 5e, MIS 5c and MIS 5a (ca. 120, 100, and 80 ka, respectively) and the development of inland lakes (Rose, 2010; Petraglia et al., 2010, 2011; Rosenberg et al., 2011, 2012), followed by episodes of population contraction, or even extinction, during the hyper-arid to arid phases of MIS 4 and MIS 3.

Our fieldwork at the Wadi Surdud in Yemen demonstrates that during the period of the supposed expansion of modern humans out of Africa ca. 60-50 ka, and their rapid dispersal toward southeastern Asia along the western and southern Arabian coastlines, the interior of this region was, in fact, occupied by well-adapted human groups who developed their own local technological tradition, deeply rooted in the Middle Paleolithic. Future research will likely reveal whether the archaeological assemblages recovered from the Wadi Surdud can be associated with the descendents of anatomically modern human groups who occupied the Arabian Peninsula during MIS 5 or the southernmost expansion of the Neanderthals.

\section{Acknowledgements}

The international Paleo-Y paleoanthropological research project, developed since 2005 by R.M. in agreement with the Yemeni General Organization for Antiquities and Museums (GOAM) and the Centre Français d'Archéologie et de Sciences Sociales de Sanaa (CEFAS), has been supported by the French Ministry of Foreign Affairs (to R.M.), the French CNRS Eclipse II project (to R.M.) and the L.S.B. Leakey Foundation (to A.D.). The Paleo-Y project was initiated thanks to the generous help of A. de Maigret (University of Naples) and J.-F. Jarrige (CNRS), and greatly benefited from the support of the University of Bordeaux 1 (UMR PACEA CNRS), the University of Poitiers (Department of Geosciences), the French Institut National de Recherches Archéologiques Préventives (INRAP), and also from the collaboration of the French Muséum National d'Histoire Naturelle and the University 'La Sapienza' of Rome. For research permission and collaboration, Paleo-Y is indebted to A. Ba-Wazir, General Director of the GOAM, A. Garallah, Deputy of the GOAM, and A.A. Mohsen, Governor of Al-Mahqwid. We acknowledge the extraordinary and continual support provided by J. Lambert and $M$. Tuchscherer, directors of CEFAS. The archaeological excavations at SD1 and SD2 were carried out under scientific direction of A.D. and J.J., respectively. In addition to the authors of this study, during the last years of the Paleo-Y fieldwork in Tihama, research at Wadi Surdud has benefited from contributions from E. Abbate, N. Abdulbaset, A. Abraudey, K. Al-Haj, M. Al-Halabi, A.S. Alrudy, A. Ballah, S. Boulogne, A. Coppa, E. Messager, H. Murad, M.A. Qasam, C. Thiébaut, P. Voinchet, and also received the friendly support of E.H. Awadh, A.M. Farea, I. Hehmeyer, and E. Keall, of the Granary's Museum of Zabid, and M.A. Al-Sayyani and M. Rajeh Murad of the GOAM. Additional research on the geo-mineralogical, geochemical, and paleoenvironmental aspects has been developed in France by
M. Frouin, C. Hatté, A. Meunier, and A. Queffelec. M.-C. Noël and $\mathrm{H}$. Goubar respectively assured most of the administrative and logistical aspects during fieldwork in Yemen. Thanks are also due to S. Antonini, S. Cleuziou, V. Eisenman, A. Froment, M.-L. Inizan, A.-M. Lézine. We are sincerely grateful to the people of the AlMahqwid and Tihama regions for their welcome and interest in our research and acknowledge the support of A. Auotnan, representative of the District of Khamis Bani Saad. The spatial analysis of S. Boulogne (INRAP) and F. Lacrampe-Lacuyaubère (Archéosphère), the final layout of the lithic drawings by G. Devilder (PACEA) and the editing of the text by B. Gravina (PACEA) have significantly enhanced the present paper. Our study has greatly benefited from the comments of R. Dennell, F. d'Errico, D. Begun, the JHE associate editor, and the suggestions of three anonymous reviewers.

\section{Appendix A. Supplementary material}

Supplementary data related to this article can be found online at doi:10.1016/j.jhevol.2012.03.008.

\section{References}

Abi-Rached, L., Jobin, M.J., Kulkarni, S., McWhinnie, A., Dalva, K., Gragert, L., Babrzadeh, F., Gharizadeh, B., Luo, M., Plummer, F.A., Kimani, J., Carrington, M., Middleton, D., Rajalingam, R., Beksac, M., Marsh, S.G.E., Maiers, M. Guethlein, L.A., Tavoularis, S., Little, A.-M., Green, R.E., Norman, P.J., Parham, P., 2011. The shaping of modern human immune systems by multiregional admixture with archaic humans. Science 334, 89-94.

Aitken, M., 1998. An Introduction to Optical Dating. Oxford Science Publications, Oxford.

Amirkhanov, H., 1991. Palaeolithic in South Arabia. Scientific World, Moscow (in Russian).

Amirkhanov, H., 1994. Research on the Palaeolithic and Neolithic of Hadramaut and Mahra. Arab. Archaeol. Epigr. 5, 217-228.

Armitage, S.J., Jasim, S.A., Marks, A.E., Parker, A.G., Usik, V.I., Uerpmann, H.P., 2011 The southern route "Out of Africa": evidence for an early expansion of modern humans into Arabia. Science 331, 453-456.

Bailey, G., 2009. The Red Sea, coastal landscapes, and hominin dispersals. In: Petraglia, M.D., Rose, J.J. (Eds.), The Evolution of Human Populations in Arabia. Paleoenvironments, Prehistory and Genetics. Springer, London, pp. 15-37.

Bailey, G., King, G., 2011. Dynamic landscapes and human dispersal patterns; tectonics, coastlines, and the reconstruction of human habitats. Quatern. Sci. Rev. 30, 1533-1553.

Bailey, G., Flemming, N., King, G., Lambeck, K., Momber, G., Moran, L. AL-Sharekh, A., Vita-Finzi, C., 2007. Coastlines, submerged landscapes, and human evolution: the Red Sea basin and the Farasan Islands. J. Isl. Coast. Archaeol. 2 (2), 127-160.

Beyin, A., 2006. The Bab al Mandab vs. the Nile-Levant: an appraisal of the two dispersal routes for early modern humans out of Africa. Afr. Archaeol. Rev. 23, 5-30.

Beyin, A., Shea, J.J., 2007. Reconnaissance of prehistoric sites on the Red Sea coast of Eritrea, NE Africa. J. Field Archaeol. 32, 1-16.

Boëda, E., 1982. Etude expérimentale de la technologie des pointes Levallois. In: Cahen, D., URA 28 du CRA du CNRS (Eds.), Tailler! Pour quoi faire: préhistoire et technologie II. Studia Praehistorica Belgica, Tervuren, pp. 23-56.

Boëda, E., 1988. Le concept Levallois et évaluation de son champ d'application. In: Otte, M. (Ed.), 1988. L'Homme de Néandertal, vol. 4. La Technique. ERAUL, Liège, pp. 13-26.

Boëda, E., 1995. Levallois: a volumetric construction, methods, a technique. In: Dibble, H.L., Bar-Yosef, O. (Eds.), The Definition and Interpretation of Levallois Technology. Plenum Press, Harvard, pp. 41-68.

Brandt, S.A., Brook, G.A., 1984. Archaeological and paleoenvironmental research in Northern Somalia. Curr. Anthropol. 25, 119-121.

Burns, S.J., Fleitmann, D., Matter, D., Neff, U., Mangini, A., 2001. Speleothem evidence from Oman for continental pluvial events during interglacial periods. Geology 29, 623-626.

Campbell, M.C., Tishkoff, S.A., 2008. African genetic diversity: implications for human demographic history, modern human origins, and complex disease mapping. Ann. Rev. Genomics. Hum. Genet. 9, 403-433.

Carto, S.L., Weaver, A.J., Hetherington, R., Lam, Y., Wiebe, E.C., 2009. Out of Africa and into an ice age: on the role of global climate change in the late Pleistocene migration of early modern humans out of Africa. J. Hum. Evol. 56, 139-151.

Caton-Thompson, G., 1938. Geology and archaeology of the Hadramaut, southern Arabia. Nature 142, 139-142.

Caton-Thompson, G., 1953. Some Palaeoliths from South Arabia. Proc. Prehist. Soc. 19, 189-218. 
Chiaroni, J., Underhillb, P.A., Cavalli-Sforza, L.L., 2009. Y chromosome diversity, human expansion, drift, and cultural evolution. Proc. Nat. Acad. Sci. 106, 20174-20179.

Clark, J.D., 1982. The cultures of the Middle Paleolithic/Middle Stone Age. In: Clark, J.D. (Ed.), Cambridge History of Africa. Cambridge University Press, Cambridge, pp. 248-341.

Clark, J.D., 1988. The Middle Stone Age of East Africa and the beginnings of regiona identity. J. World Prehist. 2, 235-305.

Clark, J.D., 1989. The origins and spread of modern humans: a broad perspective on the African evidence. In: Mellars, P., Stringer, C. (Eds.), The Human Revolution: Behavioural and Biological Perspectives on the Origins of Modern Humans. Edinburgh University Press, Edinburgh, pp. 565-587.

Clemens, S.C., Prell, W.L., 2003. A 350,000 year summer-monsoon multi-proxy stack from the Owen Ridge, northern Arabian Sea. Marine Geol. 201, 35-51.

Cohen, A.S., Stone, J.R., Beuning, K.R.M., Park, L.E., Reinthal, P.N., Dettman, D. Scholz, C.A., Johnson, T.C., King, J.W., Talbot, M.R., Brown, E.T., Ivory, S.J., 2007. Ecological consequences of early Late Pleistocene megadroughts in tropical Africa. Proc. Nat. Acad. Sci. 104, 16422-16427.

Conard, N.J., 2010. Cultural modernity: consensus or conundrum? Proc. Nat. Acad. Sci. 107 (17), 7621-7622.

Copeland, L., 1975. The Middle and Upper Palaeolithic in Lebanon and Syria in the light of recent research. In: Wendorf, F., Marks, A.E. (Eds.), Problems in Prehistory: North Africa and the Levant. Southern Methodist University Press, Dallas, pp. 317-350.

Crassard, R., 2008. La Préhistoire du Yémen. Diffusions et diversités locales, à travers l'étude d'industries lithiques du Hadramawt. Archaeo Press, Oxford (BAR International Series S1842).

Crassard, R., 2009. Middle Paleolithic in Arabia: the view from the Hadramawt region, Yemen. In: Petraglia, M.D., Rose, J.J. (Eds.), The Evolution of Human Populations in Arabia. Paleoenvironments, Prehistory and Genetics. Springer, London, pp. 151-168.

Crassard, R., Thiébaut, C., 2011. Levallois points production from eastern Yemen and some comparisons with assemblages from East-Africa, Europe and the Levant In: Le Tensorer, J-M., Jagher, R. Otte, M. (Eds.), The Lower and Middle Palaeolithic in the Middle East and Neighboring Regions. ERAUL, Liège.

Delagnes, A., 2000. Blade production during the Middle Paleolithic in Northwestern Europe. In: Proceedings of 1999 Beijing International Symposium on Paleoanthropology, Acta Anthropol. Sinica (Suppl. to vol. 19), pp. 181-188.

Delagnes, A., Meignen, L., 2006. Diversity of lithic production systems during the Middle Paleolithic in France: are there any chronological trends? In: Hovers, E. Kuhn, S. (Eds.), Transitions before the Transition: Evolution and Stability in the Middle Paleolithic and Middle Stone Age. Springer, New-York, pp. 85-107 (Interdisciplinary Contributions to Archaeology).

Dennell, R., Roebroeks, W., 2005. An Asian perspective on early human dispersa from Africa. Nature 438, 1099-1104.

Dennell, R.W., Martinón-Torres, M., Bermúdez de Castro, J.M., 2011. Hominin variability, climatic instability and population demography in Middle Pleistocene Europe. Quatern. Sci. Rev. 30, 1511-1524.

Derricourt, R., 2005. Getting "Out of Africa": sea crossings, land crossings and culture in the hominin migrations. J. World Prehist. 19, 119-132.

Deshpande, O., Batzoglou, S., Feldman, M.W., Cavalli-Sforza, L.L., 2009. A seria founder effect model for human settlement out of. Africa. Proc. Biol. Sci. 276 $291-300$.

d'Errico, F., 2003. The invisible frontier: a multiple species model for the origin of behavioral modernity. Evol. Anthropol. 12, 188-202.

Fagundes, N.J.R., Ray, N., Beaumont, M., Neuenschwander, S., Salzano, F.M., Bonatto, S.L., Excoffier, L., 2007. Statistical evaluation of alternative models of human evolution. Proc. Nat. Acad. Sci. 104, 17614-17619.

Farquharson, F.A.K., Plinston, D.T., Sutcliffe, J.V., 1996. Rainfall and runoff in Yemen Hydrol. Sci. 41, 797-811.

Fernandes, C.A., 2009. Bayesian coalescent inference from mitochondrial DNA variation of the colonization time of Arabia by the hamadryas baboon (Papio hamadryas hamadryas). In: Petraglia, M.D., Rose, J.J. (Eds.), The Evolution of Human Populations in Arabia. Paleoenvironments, Prehistory and Genetics. Springer, London, pp. 89-100.

Fernandes, C.A., Rohling, E.J., Siddall, M., 2006. Absence of post-Miocene Red Sea land bridges: biogeographic implications. J. Biogeogr. 33, 961-966.

Fischer, A., Vemming Hansen, P., Rasmussen, P., 1984. Macro and micro wear traces on lithic projectile points. Experimental results and prehistoric examples. J. Danish Archaeol. 3, 19-46.

Fleitmann, D., Matter, A., 2009. The speleothem record of climate variability in Southern Arabia. C.R. Geosci. 341, 633-642.

Fleitmann, D., Burns, S.J., Pekala, M., Mangini, A., Al-Subbary, A., Al-Aowah, M. Kramers, J., Matter, A., 2011. Holocene and Pleistocene pluvial periods in Yemen, southern Arabia. Quatern. Sci. Rev. 30, 783-787.

Forster, P., Matsumura, S., 2005. Did early humans go north or south? Science 308 965-966.

Green, R.E., Krause, J., Briggs, A.W., Maricic, T., Stenzel, U., Kircher, M., Patterson, N., Li, H., Zhai, W., Hsi-Yang Fritz, M., Hansen, N.F., Durand, E.Y., Malaspinas, A.S. Jensen, J.D., Marques-Bonet, T., Alkan, C., Prüfer, K., Meyer, M., Burbano, H.A Good, J.M., Schultz, M., Aximu-Petri, A., Butthof, A., Höber, B., Höffner, B. Siegemund, M., Weihmann, A., Nusbaum, C., Lander, E.S., Russ, C., Novod, N. Affourtit, J., Egholm, M., Verna, C., Rudan, P., Brajkovic, D., Kucan, Z., Gušic, I., Doronichev, V.B., Golovanova, L.V., Lalueza-Fox, C., Rasilla de la, M., Fortea, J., Rosas, A., Schmitz, R.W., Johnson, P.L.F., Eichler, E.E., Falush, D., Birney, E.,
Mullikin, J.C., Slatkin, M., Nielsen, R., Kelso, J., Lachmann, M., Reich, D., Pääbo, S., 2010. A draft sequence of the Neandertal genome. Science 328, 710-722.

Gresham, T.H., 1984. An Investigation of an Upper Pleistocene Archaeological Site in Somalia. Master Thesis, University of Georgia.

Gunz, P., Bookstein, F.L., Mitteroecker, P., Stadlmayr, A., Seidler, H., Weber, G.W., 2009. Early modern human diversity suggests subdivided population structure and a complex Out-of-Africa scenario. Proc. Nat. Acad. Sci. 106, 6094-6098.

Hammer, M.F., Woerner, A.E., Mendez, F.L., Watkins, J.C., Wall, J.D., 2011. Genetic evidence for archaic admixture in Africa. Proc. Nat. Acad. Sci. 108, 15123-15128.

Hovers, E., 1998. The lithic assemblages of Amud Cave. Implications for understanding the end of the Mousterian in the Levant. In: Akazawa, T., Aoki, K., BarYosef, O. (Eds.), Neandertals and Modern Humans in Western Asia. Plenum Press, New York, pp. 143-163.

Hovers, E., 2009a. The Lithic Assemblages of Qafzeh Cave. Oxford University Press, New York.

Hovers, E., 2009b. The Middle-to-Upper Paleolithic transition: what news? In: Camps, M., Chauhan, P. (Eds.), Sourcebook of Paleolithic Transitions: Methods, Theories, and Interpretations. Springer, New York, pp. 455-462.

Inizan, M.-L., Ortlieb, L., 1987. Préhistoire dans la région de Shabwa au Yémen du sud (R. D. P. Yémen). Paléorient 13 (1), 5-22.

Klein, R.G., 1999. The Human Career. University of Chicago Press, Chicago.

Klein, R.G., 2008. Out of Africa and the evolution of human behavior. Evol. Anthropol. 17, 267-281.

Krause, J., Fu, Q., Good, J.M., Viola, B., Shunkov, M.V., Derevianko, A.P., Pääbo, S., 2010. The complete mitochondrial DNA genome of an unknown hominin from southern Siberia. Nature 464, 894-897.

Lahr, M.M., Foley, R., 1994. Multiple dispersals and modern human origins. Evol. Anthropol. 3, 48-60.

Lahr, M.M., Foley, R., 1998. Toward a theory of modern human origins: geography, demography and diversity in recent human evolution. Yearb. Phys. Anthropol., 137-176.

Lambeck, K., Purcell, A., Flemming, N.C., Vita-Finzi, C., Alsharekh, A.M., Bailey, G.N., 2011. Sea level and shoreline reconstructions for the Red Sea: isostatic and tectonic considerations and implications for hominin migration out of Africa. Quatern. Sci. Rev. 30, 3542-3574.

Leuschner, D.C., Sirocko, H., 2003. Orbital insolation forcing for the Indian Monsoon. A motor for global climate changes? Palaeogeog. Palaeoclim. Palaeoecol. 197, 83-95.

Li, J.Z., Absher, D.M., Tang, H., Southwick, A.M., Casto, A.M., Ramachandran, S., Cann, H.M., Barsh, G.S., Feldman, M., Cavalli-Sforza, L.L., Myers, R.M., 2008. Worldwide human relationships inferred from genome-wide patterns of variation. Science 319, 1100-1104.

Lian, O.G., Roberts, R.G., 2006. Dating the quaternary: progress in luminescence dating of sediments. Quatern. Sci. Rev. 25, 2449-2468.

Macaulay, M., Hill, C., Achilli, A., Rengo, C., Clarke, D., Meehan, W., Blackburn, J., Semino, O., Scozzari, R., Cruciani, F., Taha, A., Shaari, N.K., Raja, J.M., Ismail, P., Zainuddin, Z., Goodwin, W., Bulbeck, D., Bandelt, H.-J., Oppenheimer, S. Torroni, A., Richards, M., 2005. Single, rapid coastal settlement of Asia revealed by analysis of complete mitochondrial genomes. Science 308, 1034-1036.

Macchiarelli, R., 2009. From Africa to Asia through Arabia: models, predictions, and witnesses of first phases of human settlement. In: Suleimenov, O., Iwamoto, W. (Eds.), First Great Migrations of Peoples. UNESCO, Paris, pp. 19-25.

Manica, A., Amos, W., Balloux, F., Hanihara, T., 2007. The effect of ancient population bottlenecks on human phenotypic variation. Nature 448, 346-349.

Marks, A.E., 2008. Into Arabia, perhaps, but if so, from where? Proc. Sem. Arab. Stud. $38,15-24$

Marks, A.E., 2009. The Paleolithic of Arabia in an inter-regional context. In: Petraglia, M. Rose, J. (Eds.), The Evolution of Human Populations in Arabia. Paleoenvironments, Prehistory and Genetics. Springer Academic Publishers, London, pp. 295-308.

Martinón-Torres, M., Dennell, R., Bermúdez de Castro, J.M., 2011. The Denisova hominin need not be an out of Africa story. J. Hum. Evol. 60, 251-255.

McBrearty, S., Brooks, S., 2000. The revolution that wasn't: a new interpretation of the origin of modern human behavior. J. Hum. Evol. 39, 453-563.

McBurney, C.B.M., 1967. The Haua Fteah (Cyrenaica) and the Stone Age in the SouthEast Mediterranean. Cambridge University Press, London.

McClure, H., 1976. Radiocarbon chronology of late Quaternary lakes in the Arabian desert. Nature 263, 755-756.

McClure, H., 1978. Al-Rub' al-Khali. In: Al-Sayari, S.S., Zölt, J.G. (Eds.), Quaternary Period in Saudi Arabia. Springer, New York, pp. 252-263.

Meignen, L., 1995. Levallois lithic production systems in the Middle Palaeolithic of the Near East: the case of the unidirectional method. In: Dibble, H.L., Bar Yosef, O. (Eds.), The Definition and Interpretation of Levallois Technology. Prehistory Press, Madison, pp. 361-379.

Meignen, L., 2000. Early Middle palaeolithic blade technology in southwestern Asia. Acta Anthropol. Sinica 19 (Suppl.), 158-168.

Mellars, P., 2006a. Going East: new genetic and archaeological perspectives on the modern human colonization of Eurasia. Science 313, 796-800.

Mellars, P., 2006b. Why did modern human populations disperse from Africa $\mathrm{ca}$ 60,000 years ago? A new model. Proc. Nat. Acad. Sci. 103, 9381-9386.

Monigal, K., 2001. Lower and Middle Paleolithic blade industries and the dawn of the Upper Paleolithic on the Levant. Archaeology, Ethnology Anthropol. Eurasia 1, 11-24.

Mourre, V., 1996. Les industries en quartz au Paléolithique. Terminologie, méthodologie et technologie. Paléo 8, 205-223. 
Mourre, V., 2004. Le débitage sur enclume au Paléolithique moyen dans le SudOuest de la France. In: Congrès, Secrétariat du (Ed.), Session 5: Middle Paleolithic. Acts of the XIVth UISPP Congress. Archaeopress, Oxford, pp. 29-38 (BAR S1239).

Moyer, C., 2003. The organisation of lithic technology in the Middle and Early Upper Palaeolithic industries at the Haua Fteah, Libya. Ph.D. Dissertation, Cambridge University.

O'Connor, S., Ono, R., Clarkson, C., 2011. Pelagic fishing at 42,000 years before the present and the maritime skills of modern humans. Science 334, 1117-1121.

Parker, A., 2009. Pleistocene climate change in Arabia: developing a framework for hominin dispersal over the last 350 ka. In: Petraglia, M., Rose, J. (Eds.), The Evolution of Human Populations in Arabia. Paleoenvironments, Prehistory and Genetics. Springer Academic Publishers, London, pp. 39-49.

Parker, A., Rose, J., 2008. Demographic confluence and radiation in southern Arabia. Proc. Sem. Arab. Stud. 38, 227-244.

Parkington, J., 2001. Milestones: the impact of systematic exploitation of marine foods on human evolution. In: Tobias, P.V., Raath, M.A., Moggi-Cechi, J., Doyle, G.A. (Eds.), Humanity from African Naissance to Coming Millenia. Firenze University Press: Firenze and Witswatersrand University Press, Johannesburg, pp. 327-336.

Parr, P.J., Zarins, J., Ibrahim, M., Waechter, J., Garrard, A., Clarke, C., Bidmead, M., AlBadr, H., 1978. Preliminary report on the second phase of the northern province survey 1397/1977. Atlal 2, 29-50.

Petraglia, M.D., 2003. The lower Paleolithic of the Arabian Peninsula: occupation, adaptation and dispersal. J. World Prehist. 17, 141-179.

Petraglia, M.D., 2005. Hominin responses to Pleistocene environmental change in Arabia and south Asia. In: Head, MJ., Gibbard, P.L. (Eds.), 2005. Early-Middle Pleistocene Transitions: The Land-Ocean Evidence, vol. 247. Geological Society, London, Special Publications, pp. 305-319.

Petraglia, M.D., 2011. Trailblazers across Arabia. Nature 470, 50-51.

Petraglia, M.D., Alsharekh, A., 2003. The Middle Palaeolithic of Arabia: implications for modern human origins, behaviour and dispersals. Antiquity 77, 671-684.

Petraglia, M.D., Rose, J.J. (Eds.), 2009. The Evolution of Human Populations in Arabia. Paleoenvironments, Prehistory and Genetics. Springer, London.

Petraglia, M.D., Haslam, M., Fuller, D.Q., Boivin, N., Clarkson, C., 2010. Out of Africa: new hypotheses and evidence for the dispersal of Homo sapiens along the Indian Ocean rim. Ann. Hum. Biol. 37, 288-311.

Petraglia, M.D., Alsharekh, A., Crassard, R., Drake, N., Groucutt, H., Parker, A., Roberts, R., 2011. Middle Paleolithic occupation on a last interglacial lakeshore in the Nefud Desert, Saudi Arabia. Quatern. Sci. Rev. 30, 1555-1559.

Preusser, F., 2009. Chronology of the impact of Quaternary climate change on continental environments in the Arabian Peninsula. C.R. Geosci. 8-9, 621-632.

Preusser, F., Radies, D., Matter, A., 2002. A 16, 0000 year record of dune development and atmospheric circulation in southern Arabia. Science 296, 2018-2020.

Quintana-Murci, L., Semino, O., Bandelt, H.J., Passarino, K., Celreavey, M., Sanrachiara-Benerecetti, S., 1999. Genetic evidence of an early exit of Homo sapiens sapiens from Africa through eastern Africa. Nat. Genet. 23, 437-441.

Ranov, V.A., 1995. The "Loessic" Paleolithic in southern Tajikistan, central Asia: its industry, chronology and correlation. Quatern. Sci. Rev. 14, 731-745.

Rasmussen, M., Guo, X., Wang, Y., Lohmueller, K., Rasmussen, S., Albrechtsen, A. Skotte, L., Lindgreen, S., Metspalu, M., Jombart, T., Kivisild, T., Zhai, W., Eriksson, A. Manica, A., Orlando, L., De La Vega, F., Tridico, S., Metspalu, E., Nielsen, K., AvilaArcos, M., Moreno-Mayar, J.V., Muller, C., Dortch, J., Gilbert, M.T., Lund, O. Wesolowska, A., Karmin, M., Weinert, L.A., Wang, B., Li, J., Tai, S., Xiao, F., Hanihara, T., van Driem, G., Jha, A.R., Ricaut, F.X., de Knijff, P., Migliano, A.B., Gallego Moreno, I., Kristiansen, K., Lambert, D.M., Brunak, S., Forster, P., Brinkmann, B., Nehlich, O., Bunce, M., Richards, M., Gupta, R., Bustamante, C.D., Krogh, A., Foley, R.A., Lahr, M.M., Balloux, F., Sicheritz-Pontén, T., Villems, R. Nielsen, R., Wang, J., Willerslev, E., 2011. An Aboriginal Australian genome reveals separate human dispersals into Asia. Science 334, 94-98.

Reading, R.P., Mix, H.M., Lhagvasuren, B., Feh, C., Kane, D.P., Dulamtseren, S., Enkhbold, S., 2001. Status and distribution of khulan (Equus hemionus) in Mongolia. J. Zool. 254, 381-389.

Reich, D., Patterson, N., Kircher, M., Delfin, F., Nandinemi, M.R., Pugach, I., Ko, A.M.S., Ko, Y.-C., Jinam, T.A., Phipps, M.E., Saitou, N., Wollstein, A., Kayser, M. Pääbo, S., Stoneking, M., 2011. Denisova admixture and the first modern human dispersals into Southeast Asia and Oceania. Am. J. Hum. Genet. 89, 1-13.

Révillion, S., Tuffreau, A. (Eds.), 1994. Les Industries laminaires au Paléolithique moyen. CRA: Dossiers de documentation archéologique, vol. 18. CNRS Editions, Paris.

Reygasse, M., 1922. Note au sujet de deux civilisations préhistoriques africaines pour lesquelles deux termes nouveaux me paraissent devoir être employés. In: Paper presented at XLVIe Congrès de l'A.F.A.S. (Montpellier)

Rose, J., 2004a. New evidence for the expansion of an Upper Pleistocene population out of east Africa, from the site of Station one, northern Sudan. Cambridge Archaeological J. 14 (2), 205-216.

Rose, J., 2004b. The question of Upper Pleistocene connections between East Africa and South Arabia. Curr. Anthropol. 45, 551-555.

Rose, J., 2006. Among Arabian Sands: Defining the Palaeolithic of Southern Arabia. Ph.D. Dissertation, Southern Methodist University, Dallas.

Rose, J., 2007a. The Arabian corridor migration model: archaeological evidence for hominin dispersals into Oman during the Middle and Upper Pleistocene. Proc. Sem. Arab. Stud. 37, 1-19.

Rose, J., 2007b. The role of the Saharo-Arabian arid belt in the modern human expansion. In: From the Mediterranean basin to the Portuguese Atlantic shore:
Papers in Honor of Anthony Marks, Actas do IV Congresso de Arqueologia Peninsular. Universidade do Algarve, Algarve, pp. 57-67.

Rose, J., 2010. New light on human prehistory in the Arabo-Persian Gulf Oasis. Curr. Anthropol. 51, 849-883.

Rose, J., Petraglia, M., 2009. Tracking the origin and evolution of Human populations in Arabia. In: Petraglia, M. Rose, J. (Eds.), The Evolution of Human Populations in Arabia. Paleoenvironments, Prehistory and Genetics. Springer Academic Publishers, London, pp. 1-12.

Rose, J., Usik, V., Marks, A., Hilbert, Y., Galletti, C., Parton, A., Geiling, J.M., Černý, V., Morley, M., Roberts, R., 2011. The Nubian complex of Dhofar, Oman: an African Middle Stone Age industry in southern Arabia. PLoS ONE 6 (11), e28239.

Rosenberg, T.M., Preusser, F., Fleitmann, D., Schwalb, A., Penkman, K. Schmid, T.W., Al-Shanti, M.A., Kadi, K., Matter, A., 2011. Humid periods in southern Arabia: windows of opportunity for modern human dispersal. Geology 39, 1115-1118.

Rosenberg, T.M., Preusser, F., Blechschmidt, I., Fleitmann, D., Jagher, R., Matter, A., 2012. Late Pleistocene palaeolake in the interior of Oman: a potential key area for the dispersal of anatomically modern humans out-of-Africa? J. Quatern. Sci. 27, 13-16.

Scheinfeldt, L.B., Soi, S., Tishkoff, S.A., 2010. Working toward a synthesis of archaeological, linguistic, and genetic data for inferring African population history. PNAS 107 (suppl. $n^{\circ} 2$ ), 8931-8938.

Scholz, C.A., Johnson, T.C., Cohen, A.S., King, J.W., Peck, J.A., Overpeck, J.T., Talbot, M.R. Brown, E.T., Kalindekafe, L., Amoako, P.Y.O., Lyons, R.P., Shanahan, T.M. Castañeda, I.S., Heil, C.W., Forman, S.L., McHargue, L.R., Beuning, K.R., Gomez, J., Pierson, J., 2007. East African megadroughts between 135 and 75 thousand years ago and bearing on early-modern human origins. Proc. Nat. Acad. Sci. 104, 16416-16421.

Scott-Jackson, J., Scott-Jackson, W., Rose, J., Jasim, S., 2008. Investigating Uppe Pleistocene stone tools from Sharjah, UAE: Interim report. Proc. Sem. Arab. Stud. $38,43-54$

Shea, J.J., 2003. The Middle Paleolithic of the east Mediterranean Levant. J. World Prehist. 17 (4), 313-394.

Shea, J.J., 2008. The lower and Middle Paleolithic in the Middle east and neighboring regions. Evol. Anthropol. 17, 205-207.

Shea, J.J., 2010. Homo sapiens is as Homo sapiens was. Behavioral variability versus "behavioral modernity" in Paleolithic archaeology. Curr. Anthropol. 52 (1), 1-35.

Shea, J.J., Sisk, M.L., 2010. Complex projectile technology and Homo sapiens dispersa into western Eurasia. PaleoAnthropology 2010, 100-122.

Siddall, M., Rohling, E.J., Almogi-Labin, A., Hemleben, C., Meischner, D., Schmelzer, I. Smeed, D.A., 2003. Sea-level fluctuations during the last glacial cycle. Nature $423,853-858$.

Stokes, S., Bray, H., 2005. Late Pleistocene eolian history of the Liwa region. Arabian Peninsula. Geol. Soc. Am. Bull. 117, 1466-1480.

Stringer, C., 2000. Coasting out of Africa. Nature 405, 24-27.

Tishkoff, S.A., Reed, F.A., Friedlaender, F.R., Ehret, C., Ranciaro, A., Froment, A Hirbo, J.B., Awomoyi, A.A., Bodo, J.-M., Doumbo, O., Ibrahim, M., Juma, A.T. Kotze, M.J., Lema, G., Moore, J.H., Mortensen, H., Nyambo, T.B., Omar, S.A., Powell, K., Pretorius, G.S., Smith, M.W., Thera, M.A., Wambebe, C., Weber, J.L. Williams, S.M., 2009. The genetic structure and history of Africans and African Americans. Science 324, 1035-1044.

Tixier, J., 1958-1959. Les pièces pédonculées de l'Atérien. Libyca 6-7, 127-158.

Valladas, H., Mercier, N., Froget, L., Hovers, E., Joron, J.L., Kimbel, W.H., Rak, Y., 1999. TL dates for the Neanderthal site of the Amud Cave. Israel. J. Archaeol. Sci. 26 259-268.

Van Beek, G.W., Cole, G.H., Jamme Aluf, G.H., 1963. An Archaeological Reconnaissance in Hadramaut: A Preliminary Report. Ann. Rep. Smithsonian Inst. Washington DC. 521-545

Van Peer, P., Vermeersch, P., 1990. Middle to Upper Palaeolithic transition: the evidence from the Nile valley. In: Mellars, P. (Ed.), The Emergence of Modern Humans. An Archaeological Perspective. Edinburgh University Press, Edinburgh, pp. 139-159.

Wahida, G., Al-Tikriti, W.Y., Beech, M., 2008. Barakah: a Middle Palaeolithic site in Abu Dhabi Emirate. Proc. Sem. Arab. Stud. 38, 55-64.

Walter, R.C., Buffler, R.T., Bruggemann, J.H., Guillaume, M.M.M., Berhe, S.M., Negassi, B., Libsekal, Y., Cheng, H., Edwards, R.L., von Cosel, R., Néraudeau, D. Gagnon, M., 2000. Early human occupation of the Red Sea coast of Eritrea during the last interglacial. Nature 405, 65-69.

Wendorf, F., Schild, R., 1974. A Middle Stone Age Sequence from the Central Rift Valley, Ethiopia. Ossolineum, Wroclaw, Poland.

Winney, B.J., Hammond, R.L., Macasero, W., Flores, B., Boug, A., Biquand, V., Biquand, S., Bruford, M.W., 2004. Crossing the Red Sea: phylogeography of the hamadryas baboon, Papio hamadryas hamadryas. Molec. Ecol. 13, 2819-2827.

Zarins, J., Whalen, N., Ibrahim, M., Jawad Mursi, A.A., Khan, M., 1980. Comprehensive archaeological survey program, preliminary report on the central and southwestern provinces survey: 1979. Atlal 4, 9-36.

Zarins, J., Al-Jawad, Murad, A., Al-Yish, K.S., 1981. The comprehensive archaeological survey program. A. The second preliminary report on the Southwestern Province. Atlal 5, 9-42.

Zilhão, J., 2001. Anatomically Archaic, Behaviorally Modern: The Last Neanderthals and their Destiny. Stichting Nederlands Museum voor Anthropologie en Praehistoriae, Amsterdam.

Zilhão, J., Angelucci, D., Badal-García, E., d’Errico, F., Daniel, L., Dayet, L., Douka, K., Higham, T., Martínez-Sánchez, M.J., Montes-Bernárdez, R., Murcia-Mascarós, S. Pérez-Sirvent, C., Roldán-García, C., Vanhaeren, M., Villaverde, V., Wood, R. Zapata, J., 2010. Symbolic use of marine shells and mineral pigments by Iberian Neandertals. Proc. Nat. Acad. Sci. 107, 1023-1028. 